FF-4500, UC-35

Nuclear Explosions-

Peaceful Afrlications

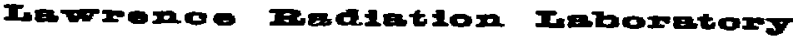 \\ Ditersity of ciliformia \\ LIVERUABe
}

UCRL-50977

\title{
COMPARISON OF CALCULATEd AND meAsuREd Response OF A HIGH-RISE BUILDING TO GROUND MOTIONS PRODUCED BY UNDERGROUND NUCLEAR DETONATIONS
}

Frank J. Tokarz

Don L. Bermreuler

MS. date: December 23, 1970

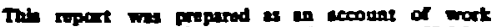
aporoced by the Unted Shita covemment, Neither

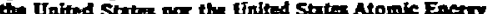

Comminion of min of thet empioyes, not any of

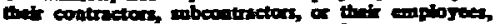

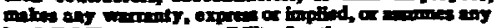

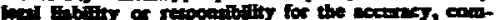

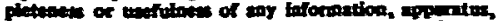

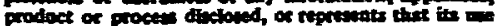

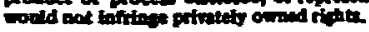




\section{Contents}

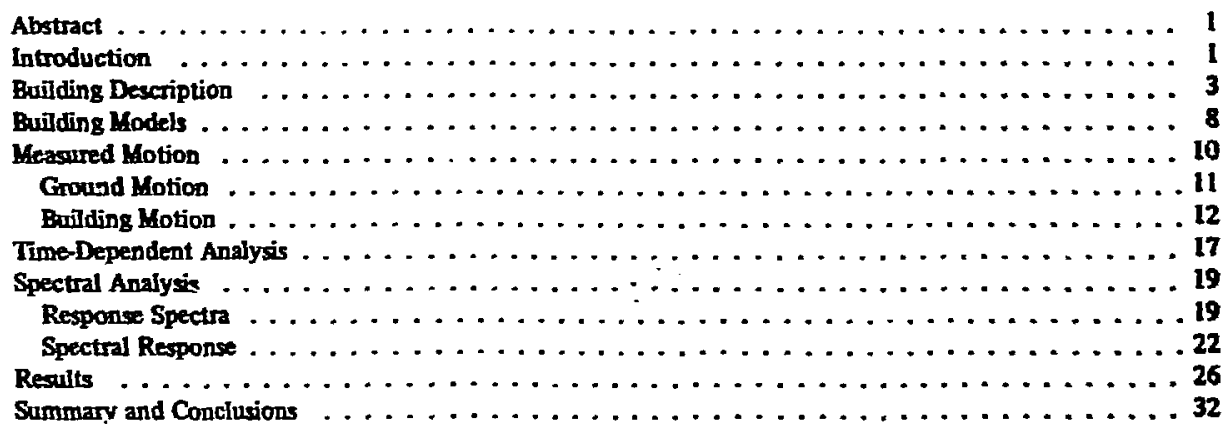




\section{COMPARISON OF CALCULATEd AND MEASUREd RESPONSE OF A HIGH-RISE BUILDING TO GROUND MOTIONS PRODUCED BY UNDERGROUND NUCLEAR DETONATIONS}

\section{Abstract}

The dynamic response of the Bank of Nerta building in Las Veges to ground motions roulting from seyeral underground nuclear desimations at the Neyada Test site is investigated. The enents chooen were Findiey. Benham, Joram, and Boxcar.

Both a time-dependent analyats, using the modal superposition method, and a spectral response analyois are peasented. A brief outline of both methods is included. The gromd motion was measured at the of the building and at NOAA-NOS seismic stations designated as SE6 and Squires Part. Measured timehistory reconds were uned as the exciting motion inputs for the anslys The peak response of the roof of the building was atso mesaured for each event. In addition, for the Fandiey Event the timehintory repportse wa mesesred at rarious kereth of the building.
A comparion was made between the calculated and measured peak responses and between time-history responses.

A study wns mide of the sensitivity of the raponse calculations to three facton: the mathematical model of the buiding, the inpot ground motions, and the vilue of viscous dumping. The results indicats that (1) reasonable modelins asumptions can lend to modeh whose cleuhted repones is quite different from the measured response; (2) when meatured ground motions as near $8800 \mathrm{~m}$ from the building are uned for the exciting motion, the calcuhted and mentred reponse vilues are different; and (3) when a pouterioni infocmation of the building (e.s., mode shapes, fundamentil periok, and dampire) is ued, it is posible to dewelop a model whove calculinted roponse apres very well with the reconded timo-history reaponse of the building.

\section{Introduction}

When plenning a nuclear event it is escentiel that rood understanding be developed of the response of building and other stnuctures to expected ground motions, and of the poxibitity of demare to such structures. It is concrivable that for future muclear detonations anocinted with the Plowhare pasorem the response of surrounding structures and property will be a controlling fector, not only for enfety considerations but in the overail plaming and fearibility deteruination of the project.

In in efiort to develop this understmding, a stonty nas undertiken to investigate the dymamic reaponse of the Bunk of Nernds (B of $N$ ) builting in Las Vegs to ground motions as the reoult of several Nerdi Tet Site (NIS) eveats. We prent here some of the revilts obtined for the reponse of the building in its longitudinal directicn. The Bink of Noreh building - wa chooen because metsured brilding rewponse data were araibble for the Findley Erent, enabling is to mike 1 comparixan between analytical and messured time-history responec. Peak reaponse dita were arilable for all the events for the $\dot{L}$ of $N$ building.

The events chocen were Bondeg, Bonham, Jorm, and Boxear. These events were considared becanes of the similarities of their yielde, depthe of burial, and goological confugurations Alo, ground motion dith existed from at lest one common measuring station for these four events.

Mast of the studies reported in the liternture on the respose of high-rise building to siemictype ground motions bine been theoretical. To obtwin sorults from such theory in practice is quite difficult for two resons. Fint, innuficiest dats exiet

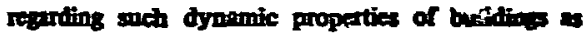
naturl periods damping material gropertices, etc. Second, there is a back of metsured inpat pound motion and/or rexponse duth for boildings with which to calculate the building's response or to compare with the cloulated response. Hence, with the exeeption of the work of Bhume ${ }^{1,3}$ and Afudeons? 
theoretical studies usually considered a hypothet. cal model of some structure, or an acturi model in conjunction with an exciting ground mation generated from a past earthquike recorv.

The degree of confidence that one can associate with any rasponse calculation depends on how well the ground motion is defined and also on the development of a reliable mathematical model of the building The dertopment of spch a model is quite diffuxalt and requires much engineering experience.

If. this study, the ground motion measured at the bese of the $B$ of $N$ building for the Handley Event is conidered as reliable input exciting motion for requese calculations. In addition, because the timulistory reponic of the boijing was mo metsured for the Hindley Event, it ma posible to dertiop a model (L6: sec section on building modets) of the building such that its ctlenlated repseagnes very well with the measured response. Since both a reliable input exciting motion and a reliable moile of the $B$ of $\mathrm{N}$ boilding exist, more meaning can be attuched to the resalts of this study.

Current practice in anatyzing the response of struetures to exthqulkoble ground motion is centered about two approsecties. One is to use a thetustory recond of the fround motion wh a mithematical model of the structure to determine a tim-history response of the model. For a particulir moded, this analysis anll yield whet mos be termed the "exact" wolution. The other approach employs spectral antyris techniques to obtuin the peik remporis of the structure. Should the spectral approuch be applied to a structure nasumed to be a dimple onodegree oxcillator, it would abo yield the "exact" peek respone for an anomed vilue of viecous dempins. Howwer, for a structore such is a highrive builting which cannot unully be repre-

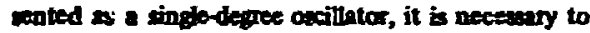
make axumptions reganding modal combination, and the antyris becoure approximate. On the other bend, should the hishtice balling vibate in it fundamentol mode (oc at leat in a combination of only a fow of its boved moda) the effect of thecramptions regationg madal combinations woold be minimized. The spectril approsch is much simpler to

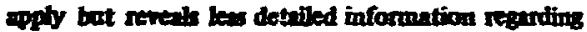
the respane of the structure then ines time-dependeat malysis.

In this sondy both appracties were exployed; a brief outine of exch method is presented. Our purpose in maling both types of aralysis wres to compare the cocurncy of the spectral method vith that of the modil superposition timebistary approach.
In order to give some insight into the sensitivity of the response calculations to parametric variations, results are included which were obtained when using (1) various mathematical models of the buildins, (2) different exciting ground motions and (3) various asumed vajues of pereent critical viscous damping. Since only cre building was studied, the resulting range of variation of the different response parameters has little quantitative meinning; however, due to the good agreement between the calculated and measured responses, the range of beharior gives a good qualitative insight for other boildings and otber posdbie exciting motions.

It should be pointed out that, although the same techniques used to andyze the reaponse of structures to seismic motions are abo used when designing them, the overall philosophy is often not the sme. Because of tive many uncertainies involved in design. conservative sosumptions are often justified. How ever, when trying to predict the response of the structure to secrithin the posible onet of damage, mech conservative sapumptions often leed to uniustfied predictions of demige. It is therefore very important that ofl the reppons parumeters used be as retistic as pomible.

In Iddition, a stencth aniysis requires detailed bnowlede of the loading and materinl properties of the individual structural members. The meterial properties inchude allowable stresses es well as the elastic constants and effective geometry required for the response anslysis. The sctual values of these quentitie are ofeen not eren deterministic. For example, resomble extimites of Young's modulus for concrete might very from $10^{6}$ pis to $6 \times 10^{6}$ psi; on allowble stres for concrete in tension might very from 0 to 300 psi; the effective crowsection properties ueed fer stiffines calculintions could vay by a factor of two or three.

Nthough, exerally, neither the sexponse calculat tion not the strength calculation is directly proportional is sech raintions, the results are getath iniluenced, particulaty the strength andysis results. Apia, much ensinering experieace and jud conent are necesary when selocting values for such quintities

Finally, should the predicted ground motion be of sech a magritude that the onenll bebrvior of the structure coss to an lineanty clestic, then any realistic resporic prodictions become extremely dificult. In fact, only conerrative annilysis can be made to ensure that no catastrophic frilure ascurs.

The ofjectives of this paper can be aummaized as follow:

(1) To tromotrate that the elentic pectral approsch and a time-dependent approach 
are capable of predicting the dynamic response of structures to seismic motion.

(2) To irdicate the advantages and the diadvantage of the tr:0 approacties.

(3) To indicate the sensitivity of the calculated response to varions mathematical models of the building, different exciting ground motions, and various values of damping

(4) To give some insight as to the precition with which the onset of poseible damage cin be escertained frum the respoise calculations.

\section{Building Description}

The Bank of Nevada is a 10-story building located in downtown Las Vegas, approximately $165 \mathrm{~km}$ from
Anta 20 of the Kerada Test Sitte (NiS). A schematis of the building is shown in Fis. I. Figure 2 shows the

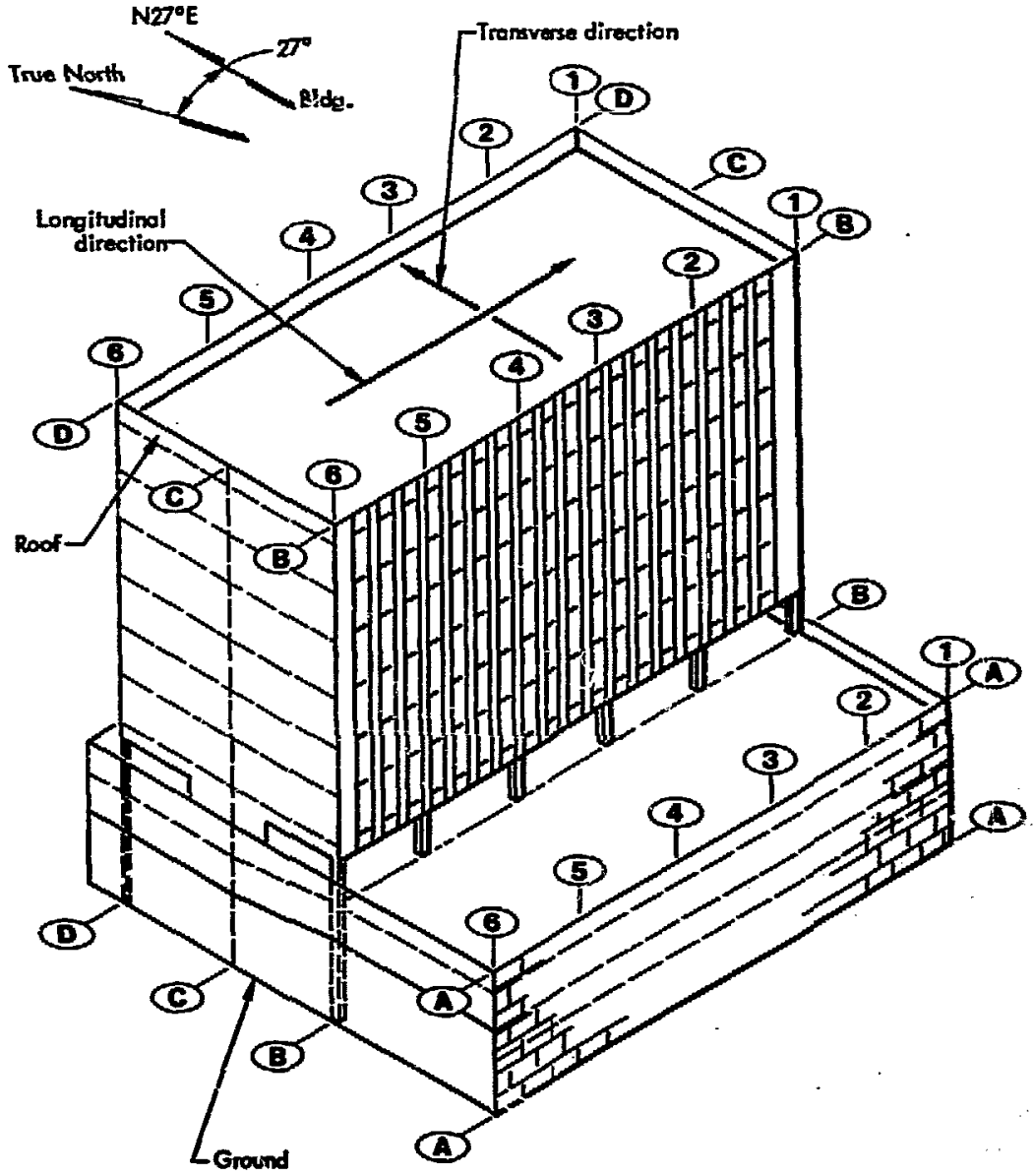

Fin 1. Schemetic of the Bunk of Nerade building 


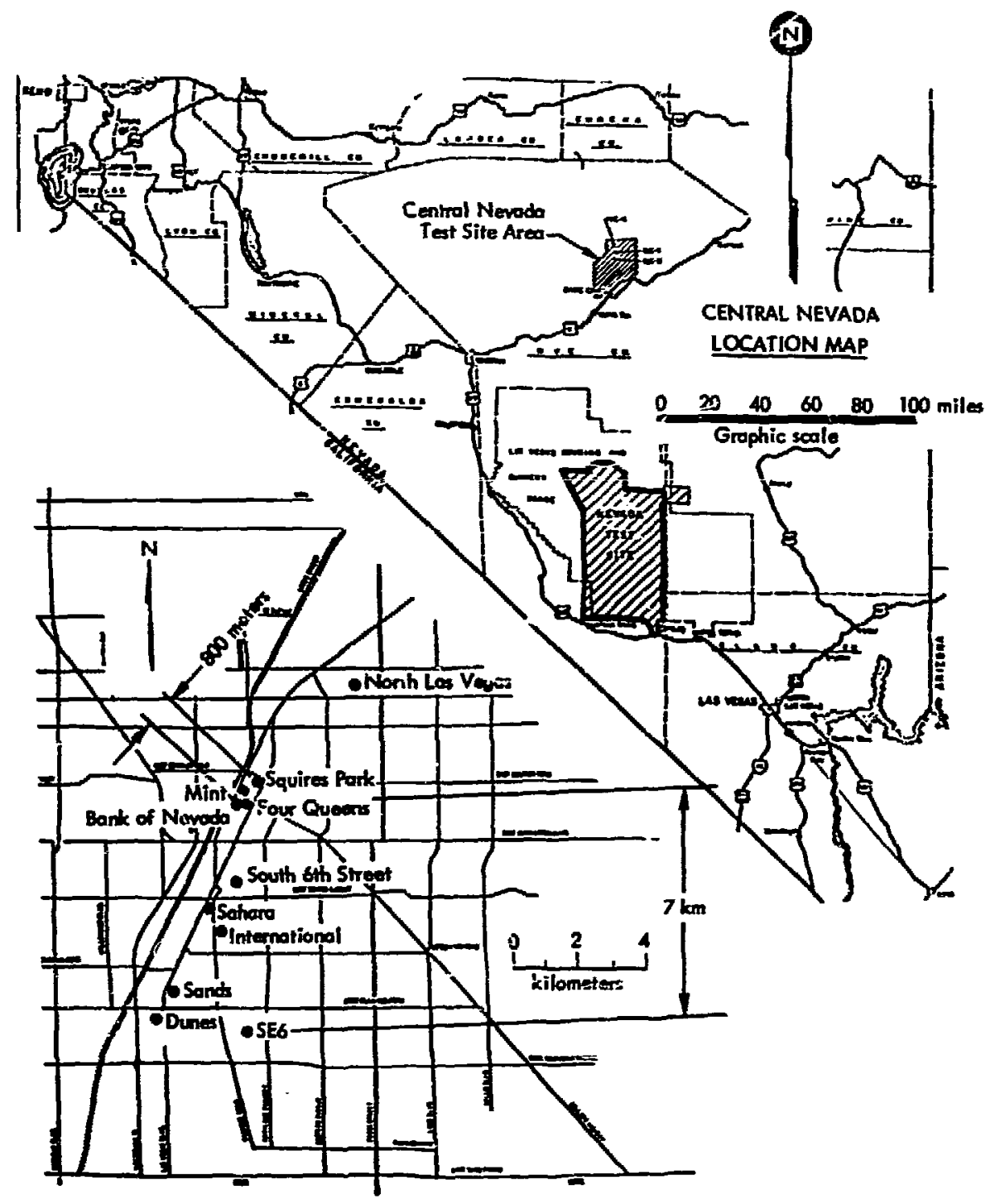

Fi2 2 Nups of NTS and vicinity and of Las Vegas.

beation of the boilding relative to NTS; also thown iro the National Oreanic and Atmopheric Administratios National Ocean Survey (NOAA-NOS) recording stations pertinent to this study (formenty U.S. Coest and Ceodetic Surney).
The upper six floors are $69 \mathrm{ft} \times 138 \mathrm{ft}$ in plan $\mathrm{A}$ puring grage exiends the lower four levels to $124 \mathrm{ft} \times 138 \mathrm{ft}$. Figures 3 and 4 show framing plans of a typical apper floor and of the third floor. Three steel frames are iocated in plines B, C, and D of Fig 1. 


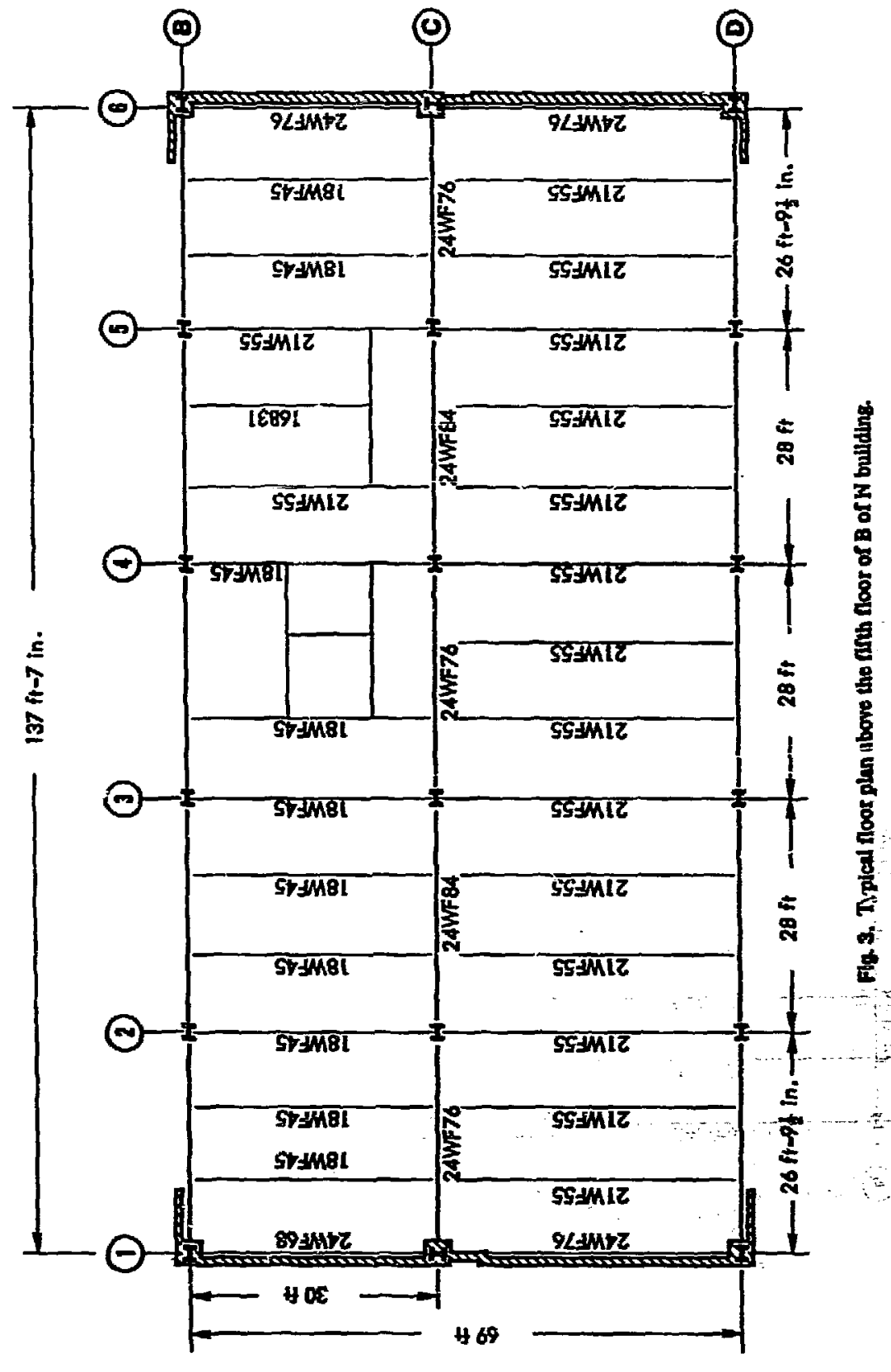




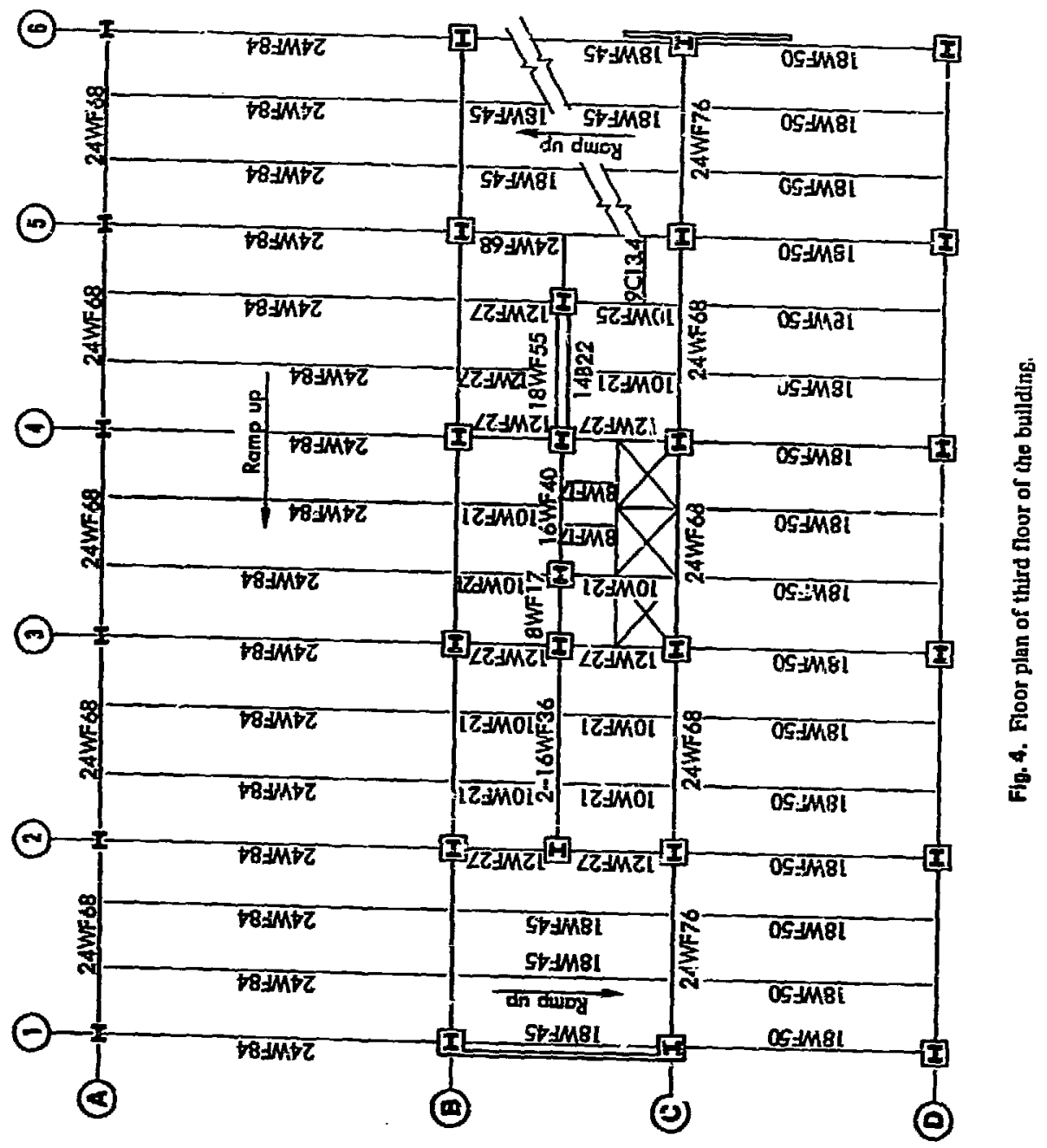




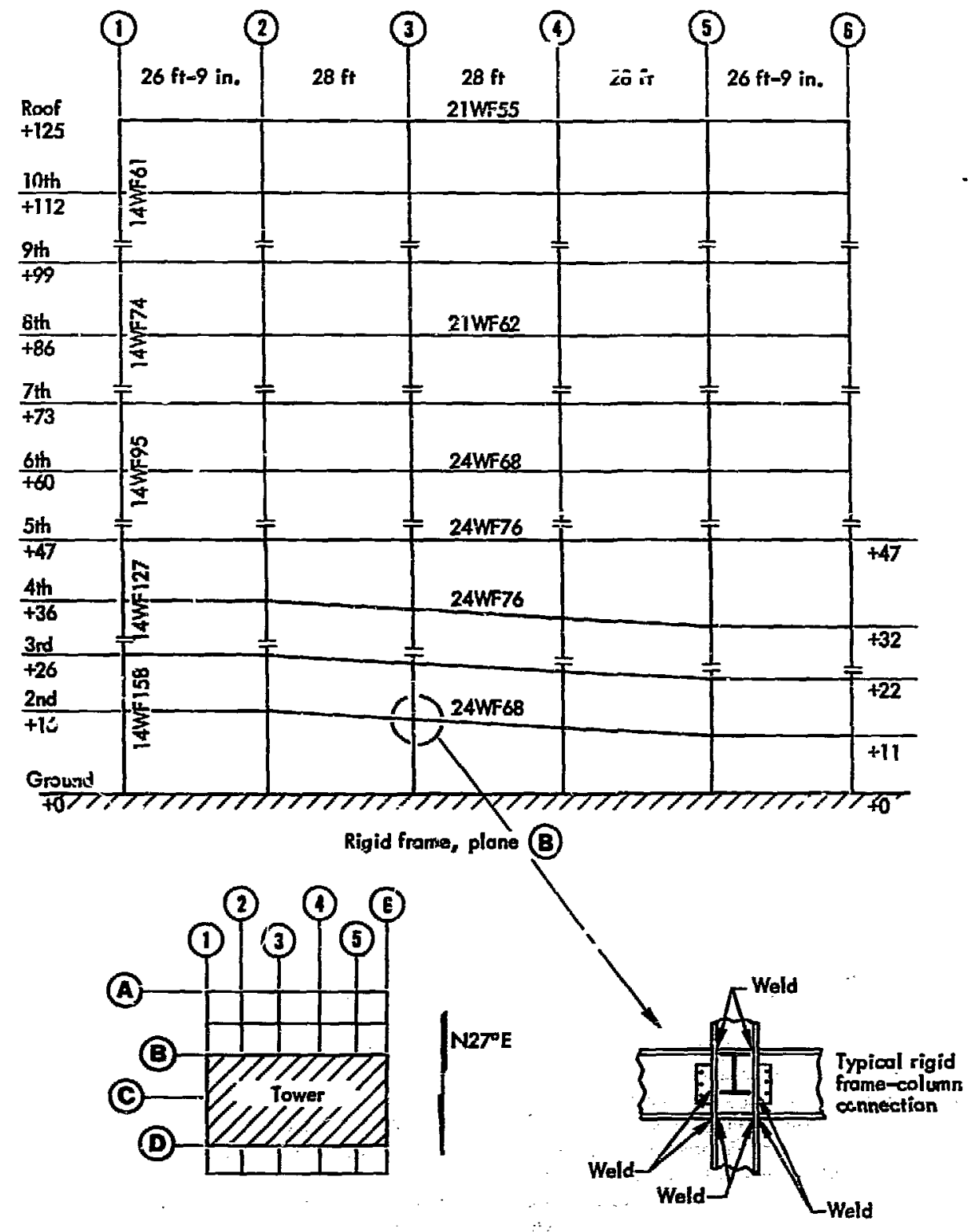

Fa 5. Rigid frame in plane B (see Fig. 1).

These frames which extend $125 \mathrm{ft}$ above the sumounding grade, consist of steel wide-llange columns and girders. The building's resistance to seismic and wind forces in the longitudinal direction 
rests primarily with these three steel frames. Reinforced concrete slabs (4/2 in. thick) at each floor provide a sufficienty rigid horizontal diaphragm to allow us to assume that the three frames displace identically to longitudinal motions. An elevation view of the frame in plane $B$ is shown in Fig 5. An additional steel frame with reinforced concrete block is located in plane $A$.
Two reinforced concrete walls ( 8 in. thick) extend from the roof to the ground level in planes 1 and 6 . In addition, walls oi reinforced concrete and reinforced concreta block are located along these planes in the tower iour levels. In the transverse dincetion seismic and wind forces are resisted primarily by the two shear walls located in planes 1 and 6.

\section{Building Models}

Several mathematical models of the $B$ of $N$ building were developed. All the models are considered to represent the building reasonably well Theit differences reflect the varions assumptions made about the structural behavior of the buildingThese asumptions in turn reflect any tnown information about past dynamic behavior of the building-For example, if no information vere available regarimg the response of the building to past ground motions or eren to induced motions, then any of the models would be considered reasonable. But if information were available which establiehed, say, the fundamental period of the beuilding, then a good buildine model should reflect this inionmation.

Before procecding to a discusoin of the difterent modets, a few comments are in order reparding the Fenerl dymamic behrior of the bulding in the logitudinal direction. Above the fifth fevel the lateral lond-arying capacity rests with three structural-steel frames in planes D, C, and D of Fig. 1. These three frames are assumed to have rigid column-girder connections. That is, full moment transer is possible between the columns and girders. This assumption might be questionable vith argard to the frame in pine $C$ Befow the inth level the builting's longitudinal dynamic beharior is determined not only by these three frames (which extend to ground level). but also by the rigitity introduced by the parkine gange. Measurements of building motion during the Handley Exent indicate that the fourth and ground levels displaced longitudinally tosether. This implies that the paring parage introduces a substantial incrcase in rigidity in these lower levels. Should this be irve, lateral shear would be transferred to the soil bencath the building primarily through the concreteblock wall in plane $A$. Otherwise, the lateral shear would be transferred to the soil through eighteen ziread footings (one at the base of each of the frame columns).
Figure 6 illustrates the basic differences among five of the nodels investiogted. The moils are iesignated as $L 1, L 2, L A, L 5$, and $L 6$ and have rundamental periods of $1.90,158,1.12,1.72$, and $1.46 \mathrm{sec}$, respectively. The first three mode shapes are shown for exch model. AH the models are assumed fixed at ground level. The effect of soi-structure interaction is not included in the study.

For models $\mathrm{Ll}$ and LS the actual stiffness values were assigned to all the colomns and girders. These values were melalated from the drawings of the building. The firder stiffiness included the structural steel, the $4 \%$ in. reinforced cotrcrete slab at each floor, and any concrete fircproofing. In model Ll a 3-ft portion of the slab was used to derive the girder stiffncest, wheres in model $\mathbf{L S}$ all of the slab was ured. The exterior column stiffiness for both models included all of the 8 -in. reinforced-concrete walls. The interior colum stiffnesses included the structural steel and the concrete firprooting

Hodets $L 2$ and $L 6$ reflect the possibility of greater stiffnes in the first four levels by assigning infinite stiffness to ald the columins and girders below the iffth floor. Otherwire, these models are identical to models $L 1$ and LS, respectively.

In model $L A$ the girders were assigned infinite moments of inertia and the cohumas infinite areas for axial loads. The flexurnl and shear properties of the columns were in accordance with the active properties. Model LA, therefore, represents a building deforming laterally in shear. Such a building is commonty referred to in the literature as a "shear building" Alhough the actual properties of the columns and girders will not allow this building to respond as a "intar beilding." Although the actual properties of the columns and girders will not allow this building to respond as a "Shear building," such a model is included for the sake of comparison.

The total seismic weight of the building $(13,080$ kips) was calculated according to the actual drawings 
Actual properties (all concrete offective)

Actual properties (3-ft concrote slab effective)

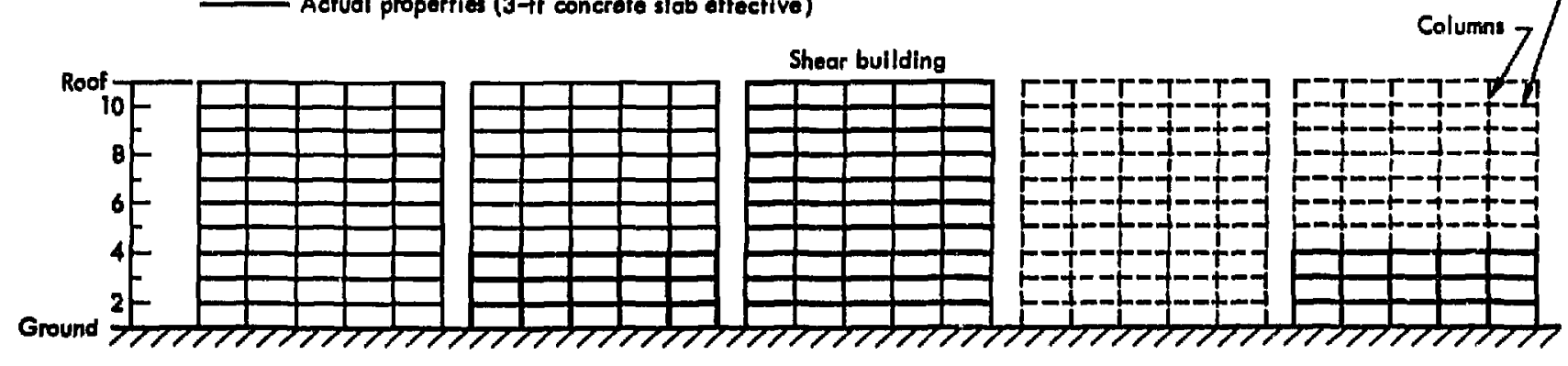

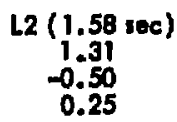
$44(1.12$ noc)
1,40
$-0.58$
L5 (1.72 800)
1.37
0.40

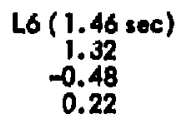

1.46
1.32
0.48

0.22

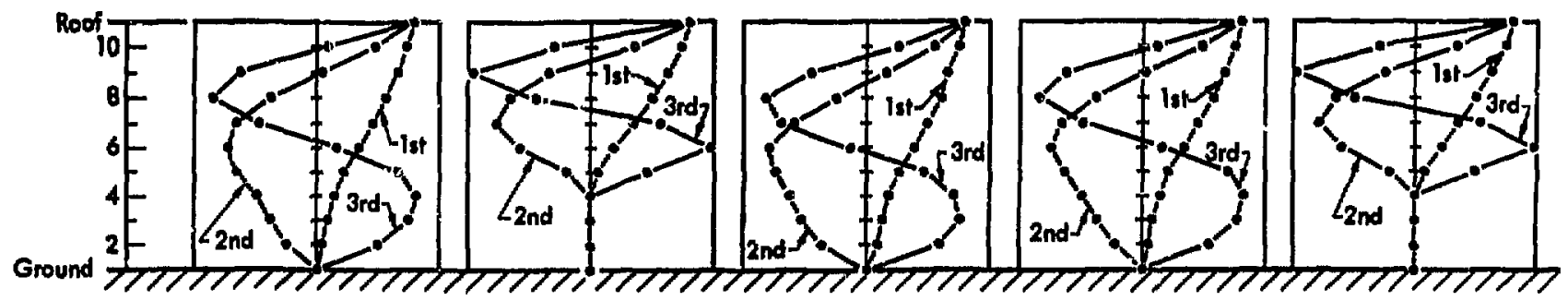

Fig. 6. Five of the building models und for the andy, designated LI, L2, LA, LS, and L6, The fint throe mode ahapes for each model se shown. Tho lowert natural period bs thown in parontheses; aleo listed aro modal participation facion fios the fint three moden. 


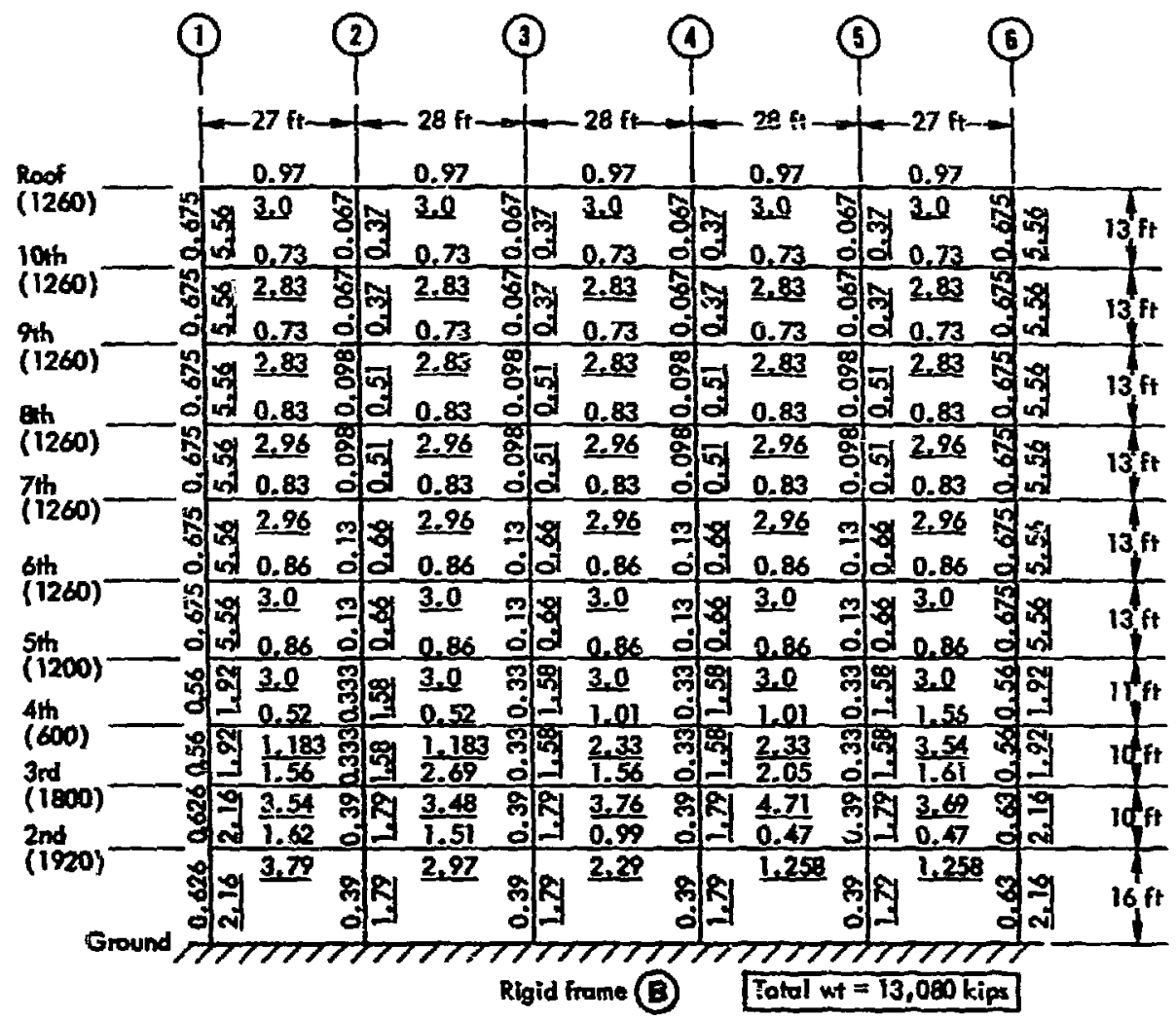

Fin 7. Geometry, weight distribution, and stifness properties of columns and ginders ueed in model 16. Nambers in parentheses under floor leves are weights, in kips, of that noor. Underlined numbers are arese, units of $n^{2}$; non-undertined numbers are second moments of area, unit of $n^{4}$.

of the beilding. The weights of the individual storie shown were soumed concentrated at the roof and floor levels. The same weight distribution was used for all models.
Thegeometry, weight distribution, andstifinesproperties of the columns and girdes used for model L6are shown in Fig. 7. These stifness properties are the sums of those calculated for frames in planes B, C, and D.

\section{Measured Motion}

Two types of measuring instruments ware wed in this study: strongmotion instruments and velocity motex. The strons-motion instruments included both - Cerder dioplecrment meter and a NOAM-NOS acelerometer (which measured and recorded three components of accelerations and displacements). The velocity meters employed were either NGC-21 or L7 (eartier models were called SCATT). These designations refer to National Geophysical Company and Precision Instrument Compiny vefority meters respectively. , $^{5}$ The stronginotion measurements were used only to obtain peak particle scoclerations 
and displacements. The mesaured velocities were recorded on analog tapes which were then procesed 6 by Environmental Rexearch Corporation (ERC) to yield 2 digital time-history of the vilocity, accelera-

\section{GROUND MOTION}

The ground-motion instrumentation was placed at. several NOAA-NOS seiemic stations in Las Veges (sec Fig. 2). We feit that ground-motion measurements at Squires Park, at SE-6, and at the base of the $B$ of $\mathbf{N}$ brilding were the most applicable to this study.

Velacity meters were used at all three stations. However, the strong-motion instruments were located only at station SE-6 and at the bax of the B of $\mathbf{N}$ building. Table 1 summarizes the peak ground motions at SE-6 and Squiris Park; the peak meanred ground motion at the base of the $B$ of $N$ building is shown in Table 2. The $563^{\circ} \mathrm{E}$ component shom in these tables coincides with the longitudinal axis of the $\mathrm{B}$ of $\mathbf{N}$ brilding, and the $\mathbf{N} 27^{\circ} \mathbf{E}$ component coincides with the building's transverse direction. (Note: the pesk particle ground motions shown are not presented to indicate their toefuiness an index of building reaponse, but rather to siow the type of veriation of ground motion that can be expected fum different events) tion, and dipplacement.

NOAA-IHOS provided and operated all the instrumentation used for motion meanurement in this study (under contract to AEC-NVO).

For all the results given in this paper the exciting ground motion took the form of a digital timo-hidory. of acceleration. This time-histony dats for the Jorim Event were derived by ERC For the Findley; Benlum, and Boxer Erents the socelerations were obtained by numaical differentiation (by the anthors) of the digital velocity datn supptied by ERC.

The original velocity dath mere reconded mary $0.00625=0$. The number of dith points ninged form about 23,000 to 45,000 (yielding a recons of approxt mately 143 to $280 \mathrm{sec}$ ). In orditer to moid bints to revise our dynamic computer program to hnodle wech a lare number of points, the number of points was reduced to about 2500. This was eccomplinhed in timo ways. Fint, instead of using erey point of the record, we selectad erery tenth point. Secoind, we uned only that partion of reound in which twe the toticated muximum pround motion.

Fipres 8 and 9 thow timohintory plote of the orighil dath usod at cround sotion input. The woro times on the figures are arbitrary and are not

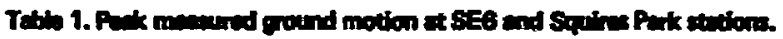

\begin{tabular}{|c|c|c|c|c|c|c|c|c|}
\hline \multirow[b]{2}{*}{ Enent } & \multirow[b]{2}{*}{$\begin{array}{l}\text { Difeo } \\
\text { tion }\end{array}$} & \multirow[b]{2}{*}{ 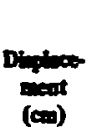 } & \multicolumn{2}{|c|}{ Sutha 885} & \multirow[b]{2}{*}{$\begin{array}{l}\text { Dines } \\
\text { the }\end{array}$} & \multirow[b]{2}{*}{ nituce } & \multicolumn{2}{|c|}{ 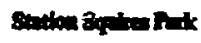 } \\
\hline & & & $\begin{array}{c}\text { Veloo } \\
(c a / b e c)\end{array}$ & Action. & & & $(0 / 6)$ & $\operatorname{ard}^{-2}$ \\
\hline \multirow[t]{2}{*}{ 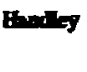 } & NS & 020 & 000 & 0.62 & $\mathrm{~kg} \mathrm{~B}$ & - & 1.52 & - \\
\hline & EMI & - & 0.51 & Q.st & 850 & - & 162 & - \\
\hline \multirow[t]{2}{*}{ Bentum } & NS & 0.20 & 109 & 0.47 & kef? & - & 1.38 & - \\
\hline & BW & 0.5 & 086 & 000 & $8 x{ }^{6} \mathrm{E}$ & - & 218 & - \\
\hline \multirow[t]{2}{*}{ Jantam } & NS & 0.31 & a71 & $\operatorname{an}$ & 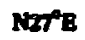 & - & 02 & - \\
\hline & EEW & $a x$ & ast & 037 & $\sin$ & - & 1.26 & - \\
\hline \multirow[t]{2}{*}{ Baxer } & NS & 0.30 & 120 & 039 & NETE & - & 106 & - \\
\hline & BW & 026 & $\mathbf{e . 7 2}$ & $a n$ & $\operatorname{ses}^{\circ} \mathrm{B}$ & - & 1.35 & - \\
\hline
\end{tabular}




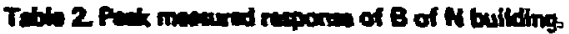

\begin{tabular}{|c|c|c|c|c|c|}
\hline Busat & Diecting & 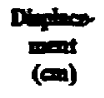 & $\begin{array}{c}\text { Volos } \\
\text { (colyece) }\end{array}$ & Acted & $\begin{array}{l}\text { Lection of } \\
\text { hetreneost }\end{array}$ \\
\hline Endry & $\begin{array}{l}863^{\circ} E \\
863^{\circ} E \\
863^{\circ} E \\
863^{\circ} E \\
863^{\circ} E \\
N 20^{\circ} E\end{array}$ & $\begin{array}{c}0.90 \\
- \\
- \\
- \\
0.99 \\
0.579\end{array}$ & $\begin{array}{c}3.87 \\
262 \\
1.53 \\
1.43 \\
1.241 .55^{*} \\
1.10\end{array}$ & $\begin{array}{c}1.80 \\
- \\
- \\
0.50 \\
\text { a.45 }\end{array}$ & 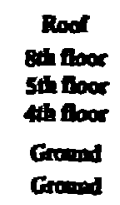 \\
\hline 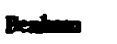 & $863^{\circ} \mathrm{E}$ & 0.85 & - & 1.50 & Roof \\
\hline Jaris & $83^{\circ} \mathrm{E}$ & 0.83 & - & 1.20 & Rod \\
\hline Dousere & S63"E & 0.92 & - & 1.40 & Rod \\
\hline
\end{tabular}

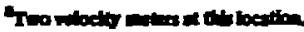

retated to each other or to travel time for the fird arivils, of the ctrea ware. The figures show the apreciable vatation in yound motion from station to chation and for the differont events. The erouts

\section{Bulloins motnoy}

N through in many cises more then one component of the motion wes recorded at the diferent stations throphout the building, only that component which coincides with the building slongitudimilaxis $\left(863^{\circ} \mathrm{E}\right)$ in incluoed.

A atrong-motion indrument whs located on the roof of the $B$ of $N$ brilding for all four crents and, as mentioned extier, atso at ground level for the Hersilley Event. Velocity meters were located on the roof, eighth, Iffth, and fourth loors, and at ground lovel for the Hindicy Exent. All these instriments were beated afproximately along a vertical centerline, the intansection of plines 4 and $C$ of Fig 1 . The were of similar yield and were all located in Area 20 of NTS. Verintions of this sort are common and indiato the difficulty in obtaining relistie input grouns motion. peak measured values recorded from these instruments are shown in Table 2. An inspection of the velocity soconds show thet these peak velocity values coens at approximately the same time.

From these (analog tape) velocity reconds, acceletation and dieplacement tiwe-history digital records were provided by ERC. Unfortunately, the acceleration reconds appeared questionable, and we feit that more work was needed to check their authenticity. Therefore, only aboohte displacement time-history reconds of the building's longitudinal motion ane inctuded. Flots of these diplacement reconds are hown for the various levels in Figs 10 through 13. 

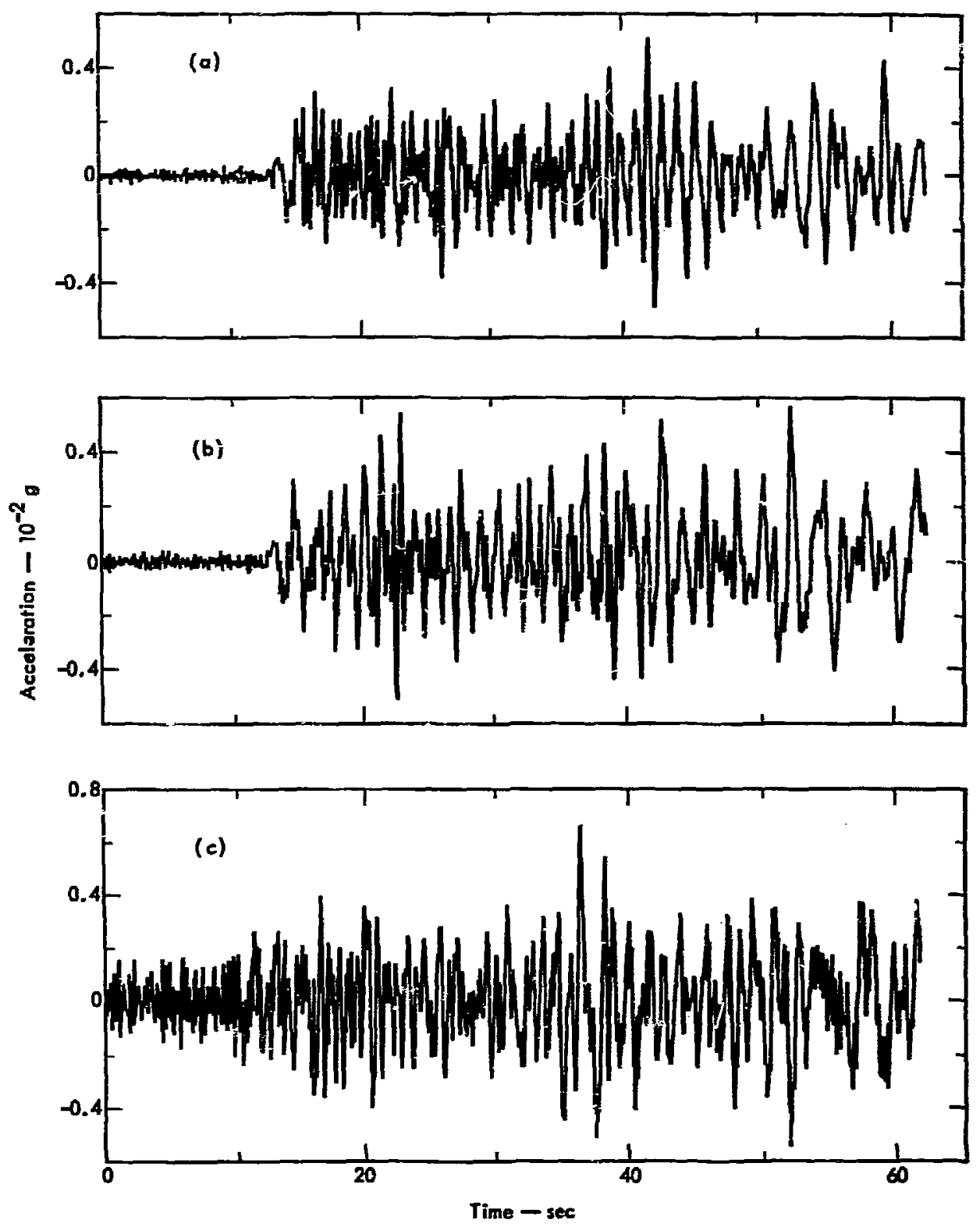

Fi4 8. Ground acceleration vs time for the Handley Event (S63 ${ }^{\circ} \mathrm{E}$ component), measured at (a) SE6, (b) Squires Park, (c) base of the building Derived from measured velocity record. 

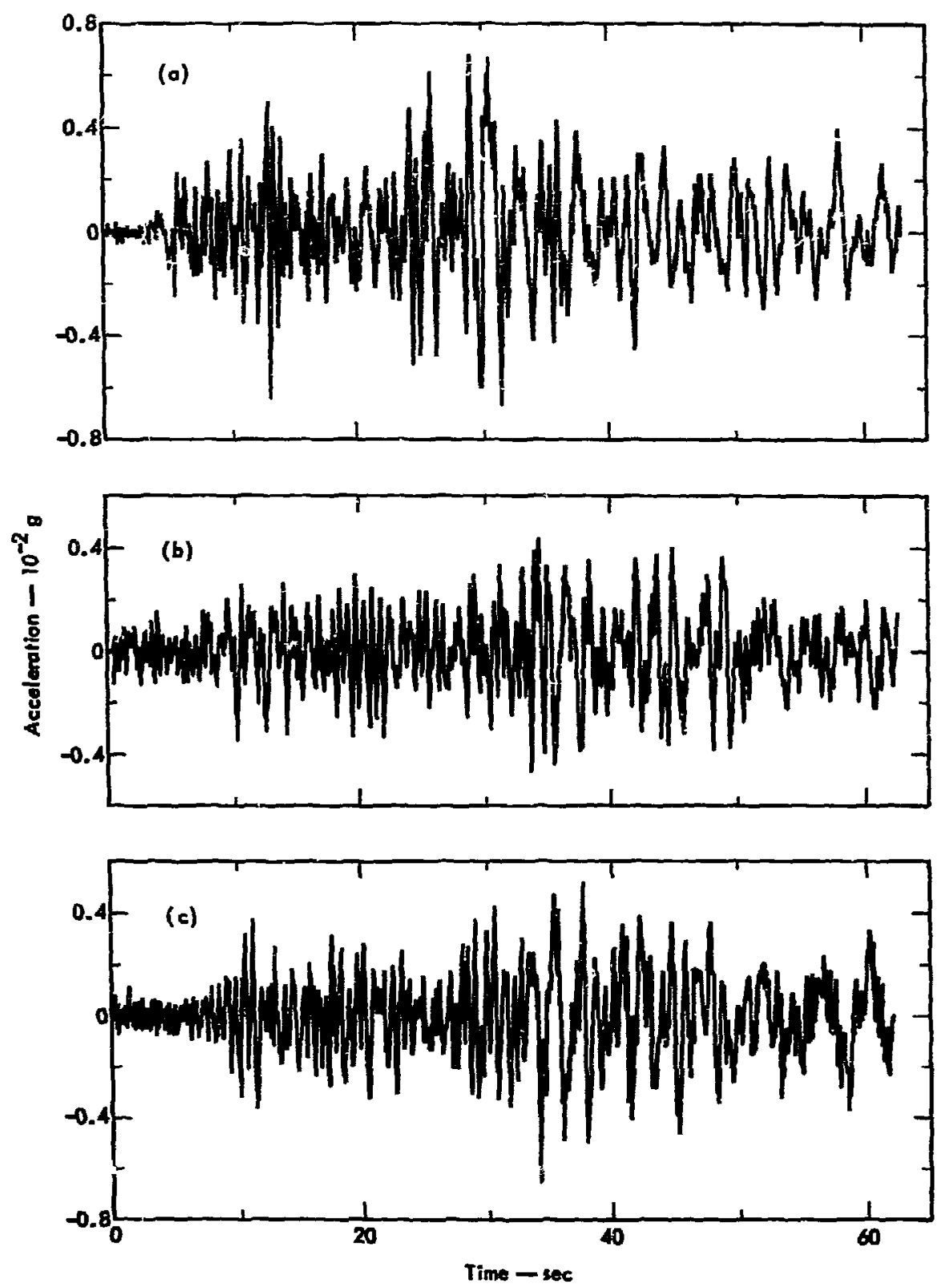

Fig. 9. Ground acoileration is time at Squires Part: (S63 ${ }^{\circ}$ E component) for erentis (a) Benham, (b) Jorum, and (c) Boxcar. Derived from mexsured velocity reconds. 


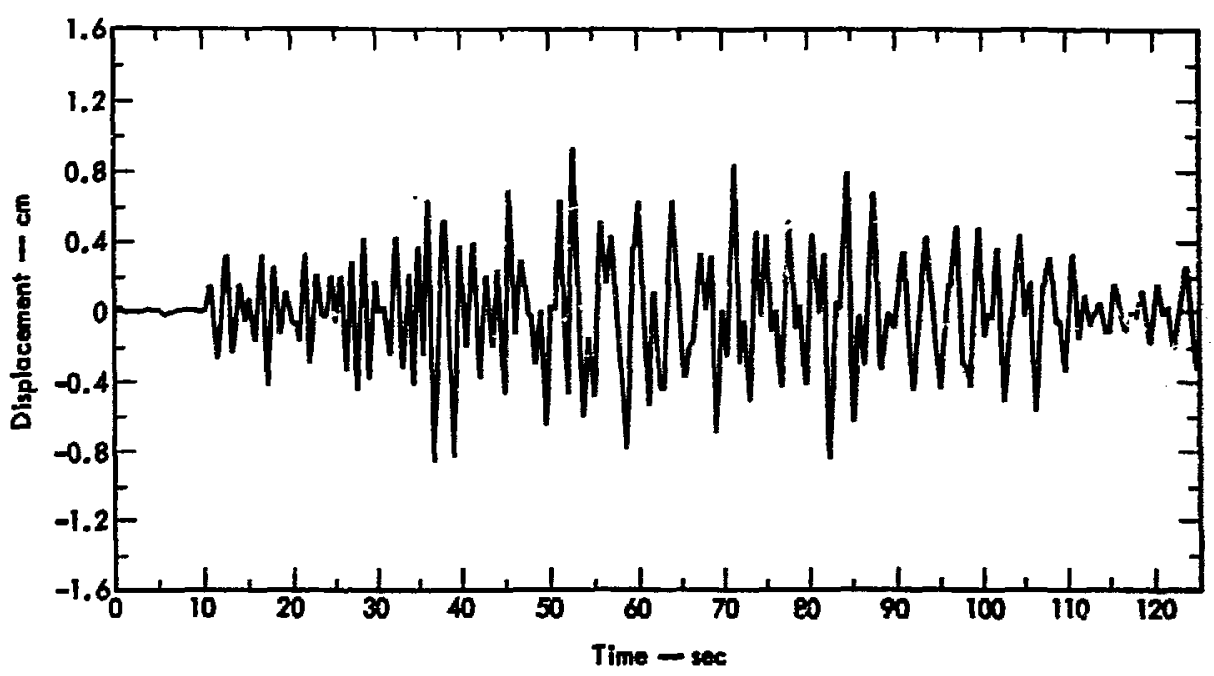

Fig. 10. Displacement is time, roof, Handley Event. Derived from meanured velocity recond.

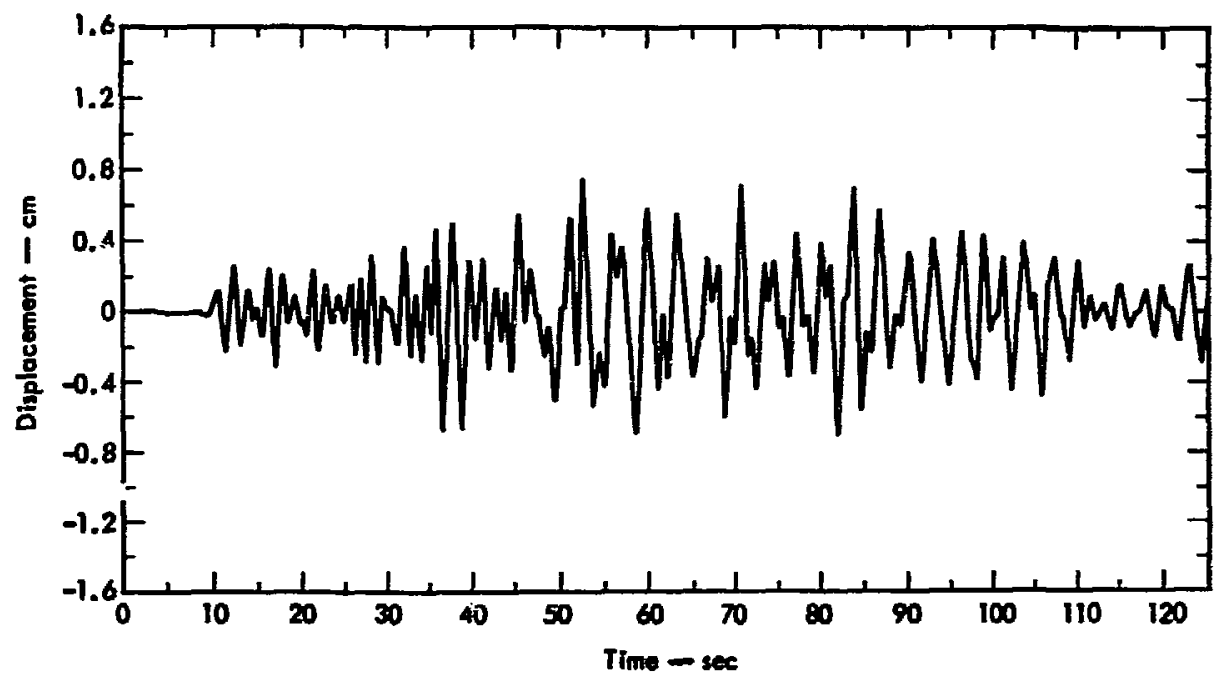

Fin 11. Disphecment is the, eighth floor, Findley Event. Derived from measured velocity recond. 


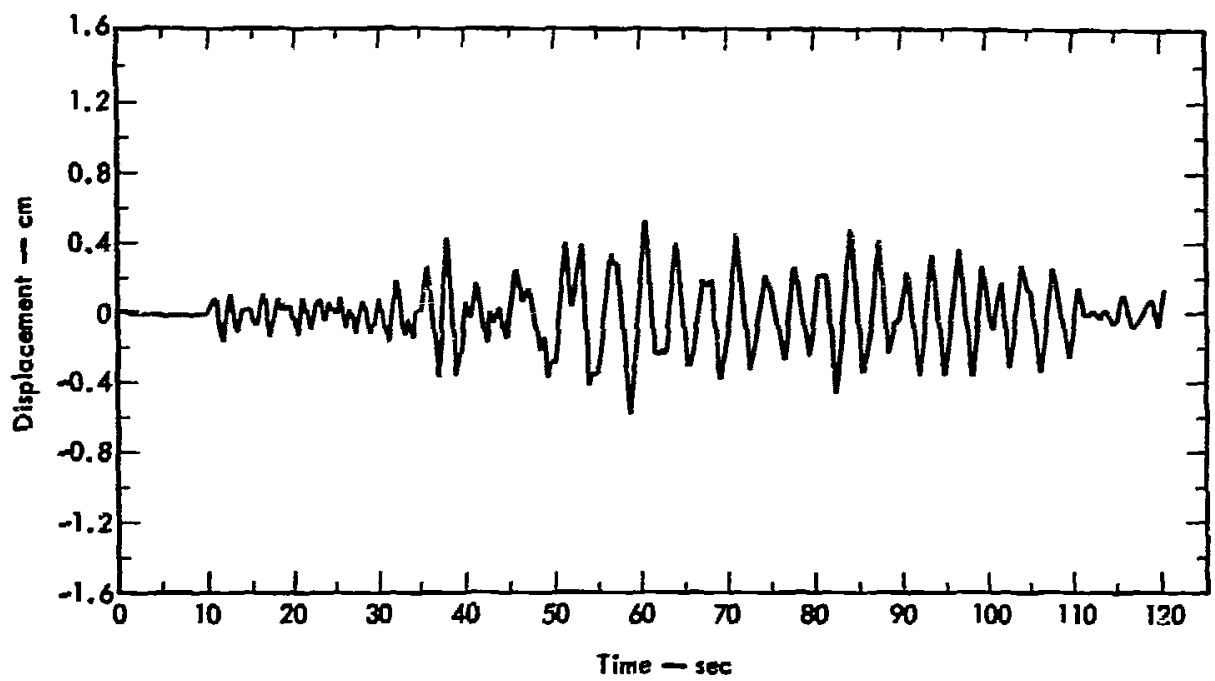

Fin 12. Displacement vs time, fifth floor, Flandley Event. Derived from measured velocity record.

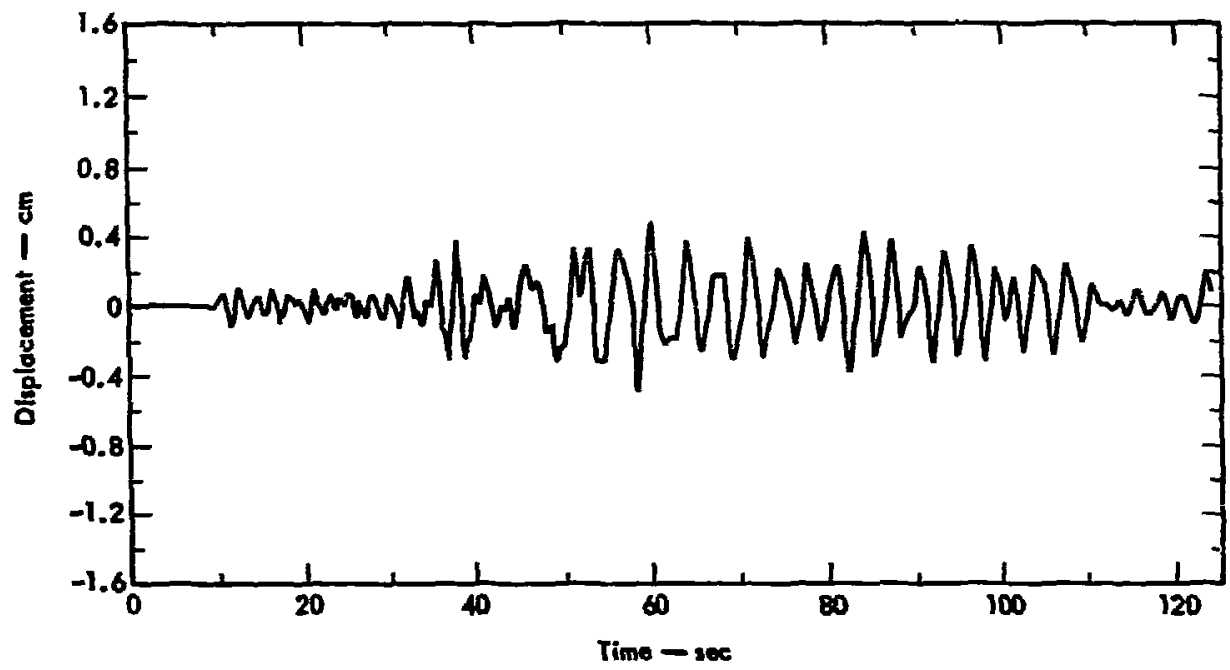

Fip 13. Disphacement ws time, ground level, Handley Event Derived from measured velucity recond. 


\section{Time-Dependent Analysis}

The time-history respons of the building to the different reconded ground motions whs obtained ty using the modal superposition method on a lumpedmas representation of the buildinz A humped-mas model is obtrined by lumping the building's inertial properties at the floor kerels and replacing the structural members with masies beam-like clements having equivalent stiffnes characteristice. Sixty humped mases were used, sach having three degress of freedom: two trandational and one rotational. The mases were located at the intersection of the columns and girlers. For more details refer to the section on Burilding Modes.s.

As gented eartier, this study is concemed with the response of the $B$ of $N$ building only in the longitudinal direction. Transverse building motions are ansumed uncoupled from bongitustinnl motions and therefore the transverse compeneat of the ground motion is not mctuded. Furthermore, the vertionl component of the ground motion intreduces neofipible longitudinal building motion. Hence, only the longtudind component of the pound motion is ued st the exciting inpert. The building b saimed fxud at ground level and only a vicourtype domping ts em ployed.

Although the procedures and to calculinge the time-dependent respone of the buildios are well dooumented throughout the bitenture, 7-9 a bief discassion is given in onder to melke this repont selfcontrined.

Once the furmped-mess model of the building hes been catabliched, the equation of motion can be enaily derived, given arbitrary ground motion. Fint, concider a system with 2 single degree of freadom a hown in Fig. 14. When the excitution of the matis we only to base motion, it is cher thet the equation of motion can be written as

$$
m x+c(\dot{x}-\dot{g})+b(x-g)=0 \text {. }
$$

$\mathbf{a r}$

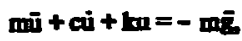

where

$x=$ absolute dioplacostont,

$\mathbf{u}=\mathbf{x}-\mathbf{z}$ the relative fiplocemont. $g=$ besce ruotion,

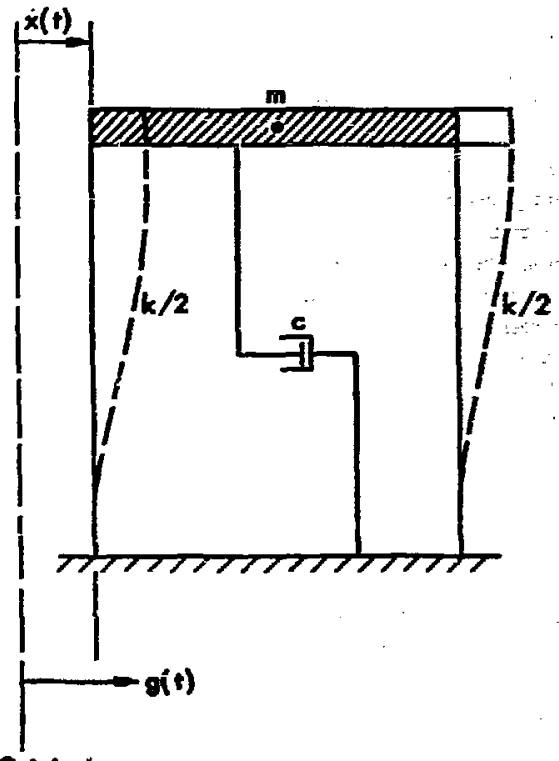

Original

position

F7 14. Syctem with one depere of fredom. $\mathrm{K}$ linear prins constut, m - miss of systras, $c$ - condent, relating dampins force to vo

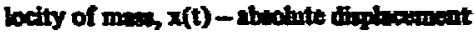
of mex $x(t)$ - abcolute fiptectiont of foor (or tround).

and the dots indicate denivitive with reploct to tince. The extention to the gytem vith mony degaes of freedom yields the following equation of motioa:

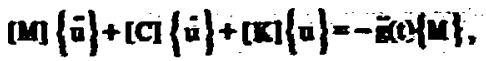

where

$$
\begin{aligned}
& \text { [M]and }\{M\}=\text { diagonl and column mess } \\
& \text { matrices, reppectiveds, } \\
& {[C]=\text { troous damping metrix, }} \\
& \text { [K] = sifines matrix, } \\
& \{\mid\}=\text { retive dioplecenent matrix } \\
& \text { (incledes notutions), }
\end{aligned}
$$

and

$\hat{g}(t)=$ input goumi accelenation. 
It cas be seen by inspecting Eqs. (1) and (2) that it is atrantageous to use relative displacements and to expros the input ground motion in terms of accelera tion.

Instead of directly integrating all the equations that comprise the matrix system (3) (in the more general case we considemd this comprived 180 equations) we simplify the problem by transforming from physical coordinates to a new coordinate system in which the equations become uncorpled into the modal equations of the structure. (For many struetures only the lower modes are of any importance in the response of the structure, so only the first few modes need to be considered.)

The key to the transformation are the eigenvalues and eizenvectors obtained from the solution of the equation

$$
\left([\mathrm{K}]-\omega_{\mathrm{i}}^{2}[\mathrm{M}]\right)\left\langle\phi_{\mathrm{j}}\right\}=\{0\} .
$$

where $\omega_{1}$ is the eigenvalue, or undamped natwal frequency, of the the mode and $\left\{\phi_{j}\right)$ is the eigenrector of the th mode. Finyically, $(6 /)$ is the modal deformation of the th mas in the th mode. The uncimped naturl frequencies $\omega_{\mathrm{f}}$ are important in the expibithment of a reltible model.

New modal cocrimates, $\eta_{2}$ are introtuced by the tranefomation

$$
\{v\}=\{\phi \mid\{\} \text {. }
$$

where ( $\phi$ ) is a motrix wose columns are the eigesvectors of Eq. (4).

Introincing the aew coordintes ints Eq. (3) and premultiphying both sidas by $[\phi]^{T}$, we obtain

$$
\begin{aligned}
& \left.[\phi]^{\top}[M](\phi]|\pi|+[\phi]^{T}[C][\phi] \mid \dot{\eta}\right) \\
& +[\phi]^{\top}[R][\phi]|\eta|=-\vec{B}(t)[\phi]^{\top}\{M \mid
\end{aligned}
$$

It is woll known from motrix theory that the eigenvectom of Bq. (4) ane orthogenal relative to the weighting factor [MI 20 that

$[\phi]^{T}[M][\phi]=\left[\begin{array}{lll}R_{1} & 0 & 0 \\ 0 & R_{2} & \\ 0 & & \\ & & R_{K}\end{array}\right]=[R]$,

where $N=$ total numbe of huped mases and $R_{i}=\sum_{j=1}^{N} m_{j} \phi_{j i}^{2}$.

Some assumption must be made relative to the damping in the system. To uncouple the modes re quires tha: $[\mathrm{C}]=a \cdot[\mathrm{K}]$, where $a$ is a scaling factor. If this is done and Eqs. (4) and (7) are used, then Eq. $(6)$ con be written as

$$
\begin{aligned}
& \{\bar{n}\}+a\left[\begin{array}{lll}
\omega_{1}^{2} & & \\
& \omega_{2}^{2} & \\
& & \omega_{N}^{2}
\end{array}\right\}\{\dot{n}\} \\
& +\left[\begin{array}{lll}
\omega_{1}^{2} & & \\
& \omega_{2}^{2} & \\
& & \omega_{N}^{2}
\end{array}\right]\{n\}=-\ddot{B}(t)[R]^{-1}[\phi]^{\top}\{M\} .
\end{aligned}
$$

The damping indicated in Eq. (8) is not of the usual form. The more standard notation is

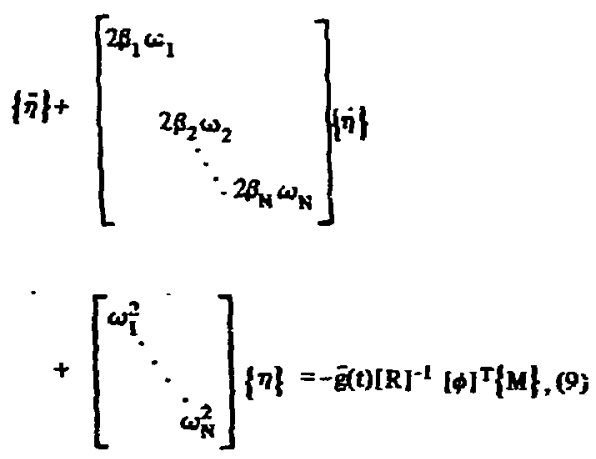

where $\beta_{\mathrm{i}}$ is the ratio of actual damping to critical viscous damping in the ith mode.

We see that Eos. (9) are uncoupled into the principal modes of the system. The equations of motion in the ith mode can aow be written as

$$
\tilde{\eta}_{i}+2 \beta_{i} \omega_{i} \dot{\eta}_{i}+\omega_{i}^{2} \eta_{i}=-\gamma_{i} \bar{g}(t),
$$


where

$$
r_{i}=[R]^{-1}[\phi]^{T}\{M\}=\frac{\sum_{j=1}^{N} m_{j} \phi_{j i}}{\sum_{j=1}^{N} m_{j} \phi_{j i} \phi_{j i}} .
$$

The quantity $\gamma$ is often referred to as the "modal participation factor."

The time-history response of the system in any one mode can be obtained by a method to be discissed later. The time-history response of the $j$ th coordinate for $\mathrm{N}$ modes is

$$
u_{j}=\sum_{i=1}^{N} \phi_{j i} \eta_{i} .
$$

All the calculations required to obtain the timehistory response were performed by a computer program called TRILIN, ${ }^{10}$ which was ieveloped in the Structural Dynamics Group of the Nuclear Test Engineering Division.

Although all the results included used input data in the form of a digital time-histary of acceleration, in sereral cases velocity input was used. To accommodate this change, the computer program was altered so that by using a special difference scheme of intogration to solve Eq. (10), a velocity input motion could be used. (This is the procedure used by ERC. ${ }^{6}$ ) For the cases presented here, no appreciable differenve was observed in the calculated respons, whether acceleration or velocity pre used as input.

\section{Spectral Analysis}

\section{RESPONSE SPECTRA}

Response spectra were developed for several reasons. First, we needed the spectra to calculate the spectral response of the various building models. Second, we wished to obtain a more quantitative feeling for the variation in measured ground motion by comparing the different spectra. Third, tiie spectra would illustrate the effect of viscous damping on the dynamic response calculations And finally, we wanted to compare the spectra we developed with those developed by ERC. This comparison would signal any enrors introdnced by our reducing the number of original data points from the measured motion records (see section on ground motion).

The name "response spectrum" is used with various meanings in the literature on the dynamic response of structures. In addition, other names, such as "pseudo-relative-velocity spectrum" (PSRV), used by ERC, have been applied to essentially the same concept. Therefore, we include a brief discussion to define these names.

"Response spectrum," as used in this paper, is defined as the maximum response of a single-degreeof-freedom system to a prescribed exciting motion of its support (or ground); this response is plotted against the undamped natural period for various frac- tional values of critical viscous damping. The response may be a measure of displacement $\left(S_{p}\right)$, velocity $\left(S_{\mathrm{j}}\right)$, or acceleration $\left(S_{\mathrm{e}}\right)$. This definition is consistent with that used in most structural engineering studies involving earthquake-like exciting motion of the support.

The "response spectrum" as defined can be developed as follows. Consider the system with one degree of freedom shown in: Fig. 14. The equilibrium equation for this system can be written as

$$
m \ddot{x}+c \dot{x}+k x=c \dot{g}+k g
$$

or

$$
m \bar{u}+c i+k u=-m \bar{s},
$$

where $u=x-g$. Either of the equations may be used to determine the response of the mass to ground (or support) motion. The choice will depend on the form of the ground motion. Equation (12) would be used if the time-history description of the ground gotion were in terms of displacement and velocity. In this study the response spectra were calculated with a previously developed 
computer code called SPONC, ${ }^{10}$ which requires input of ground motion in the form of acceleration and, therefore, Eq. (13) was used.

For convenience the damping in the system is expressed as a fraction of critical viscous damping. 6 , which in terms of the parameters of $\mathrm{Fig}_{\mathrm{g}} 14$ is $\left(2 \beta=c /(\mathrm{km})^{4}\right.$. . The spring-rrass characteristics are described by the undamped circular frequency of osciilation $\omega=(\mathrm{k} / \mathrm{m})^{\text {th }}$ or by the undamped period $T=2 \pi(m / k)^{\text {th }}$. Thus, Eq. (13) can be rewritten as

$$
\dot{\mathrm{u}}+2 \omega \beta \dot{\mathrm{u}}+\omega^{2} \mathrm{u}=-\overrightarrow{\mathrm{g}}
$$

The exact solution of the relative displacement of the mass is obtained by solving Eq. (14). It is

$$
u=\frac{-1}{\omega\left(1-\beta^{2}\right)^{4 / 2}} \int_{0}^{t} \dot{g}(\tau) e^{-\beta \omega(t-\tau)} \sin \left[\omega\left(1-\beta^{2}\right)^{4 / 2}\right.
$$$$
x(t-\tau)] d \tau .
$$

Differentiating Eq. (15), we find the relative velocity of the mass to be

$$
\begin{aligned}
& \dot{u}=-\int_{0}^{t} \tilde{g}(\tau) e^{-\beta \omega(t \cdot n)} \cos \left[\omega\left(1-\beta^{2}\right)^{4 / 2}(t-\tau)\right] d \tau \\
& +\frac{q}{\left(1-\beta^{2}\right)^{4 / 3}} \int_{0}^{t} \bar{g}(\tau) e^{-\beta \omega(1-\tau)} \sin \left[\omega\left(1-\beta^{2}\right)^{3 b}\right.
\end{aligned}
$$

$$
x(t-r)] d r
$$

and a further differentiation yields the absolute acceleration of the mass as

$$
\begin{aligned}
& \bar{x}=\frac{\omega\left(1-2 \beta^{2}\right)}{\left(1-\beta^{2}\right)^{1 / 2}} \int_{0}^{t} \bar{g}(\tau) e^{-\omega \beta(t-\tau)} \sin \left[\omega\left(1-\beta^{2}\right)^{1 / 2}\right. \\
&x(t-\tau)] d \tau+2 \omega \beta \int_{0}^{1} \bar{g}(\tau) e^{-\omega \beta(t-\tau)}
\end{aligned}
$$

$$
X \cos \left[\omega\left(1-\beta^{2}\right)^{4}(t-\tau)\right] d \tau .
$$

By definition, the relative displacenent, $S_{D}$, the relative velocity, $S_{\mathbf{r}}$, and the absoluie acceleration, $S_{2}$. are

$$
\begin{aligned}
& S_{D}=u^{\max } \\
& S_{y}=u^{\max } \\
& S_{2}=x^{\max } .
\end{aligned}
$$

Thus, for a prescribed ground acceleration $\bar{g}(t)$, the relative displacement, relative velocity, and absolute acceleration spectra can be calculnted from Eq. (18) by assuming various "alues of the natural period for some spccified percentage value of critical damping.

For the response of structures to earthquake-lik: excitation, the relative velocity spectrum and the absolute asceleration spectrum are often replaced by "pseudo relative velocity" (PSRV) and "pseudo absolute acceleration" (PSAA) spectra, defined as

$$
\operatorname{PSRV}\left(\sim S_{v}\right) \equiv \omega S_{D}
$$

and

$$
\operatorname{PSAA}\left(\simeq S_{2}\right) \equiv \frac{1}{\omega^{2}} S_{D}
$$

These spectra can be derived from Eqs. (16) and (17) by first assuming that the damping is small (say. $\beta$ less than 1096), in which case the quantity $\left(1-\beta^{2}\right)^{\text {HS }}$ may be replaced by one, then by dropping the second term of these equationg since they are of the same order of magnitude as $\phi$, and finally by replacing the cosine function in Eq. (16) by a sine function.

To evaluate the accuracy of these approximations a comparison of the PSRV and $S_{y}$ spectra are shown in Fig. 15 for assumed values of 2,5 , and $10 \%$ for viscous damping. It is seen that over the period range of 0.4-2.5 sec, and for damping values less than 10\%, the approximations introduce no significant enror. There fore, for the present study PSRV and PSAA spectra will be considered as equivalent to $S_{\text {, }}$ and $S_{a}$ spectra.

Figure 16 shows the response spectra developed from greund motions measmed at Squires Park for each of the events considered in this study for an souned 5\% critical viscous damping. In Fig 17 the response spectra are again plotted along with the spectra developed by ERC. The good agreement indicates that no appreciable error was introduced by the reduction in the number of data points from the ERC ground-motion records.

The response spectra for Inandley, generated from ground motions measured at SE6, Squires Park, and at the base of the B of $\mathrm{N}$ building, are shown in Fig. 18 . 
Variation in both the ground motion and the response can be observed in these figures. The effect of the aswmed value of viscous damping can be seen both in Fig. 15 and in Fiz. 19 where the response spectrum for Hindley was generated from ground motions meserred at the bexe of the $B$ of $N$ building for assumed values at critical viscous damping of 0,5 , and 10\%.

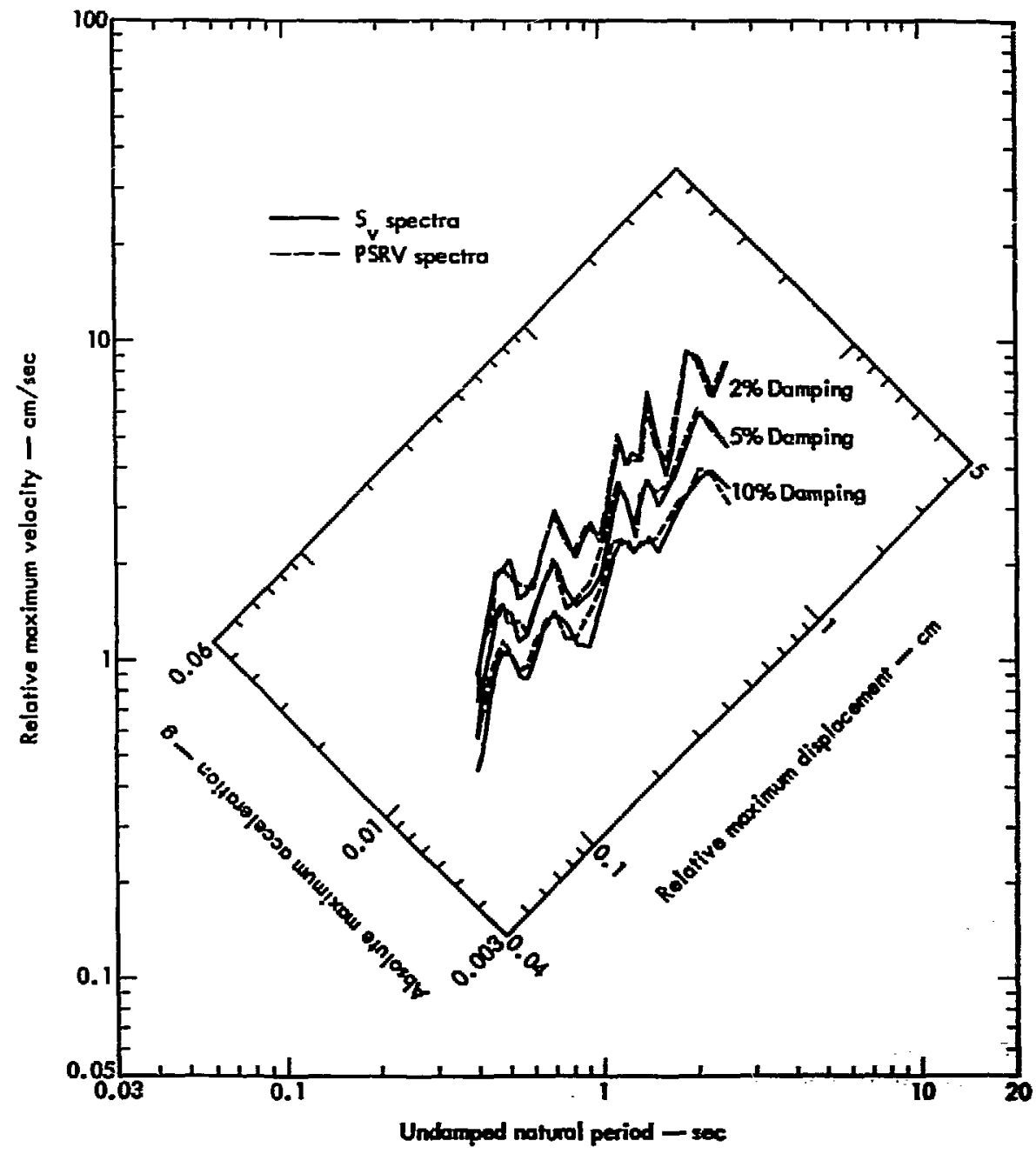

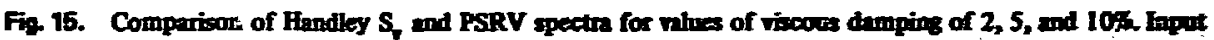
ground motions measured at Squires Pat (S630 E companent) 


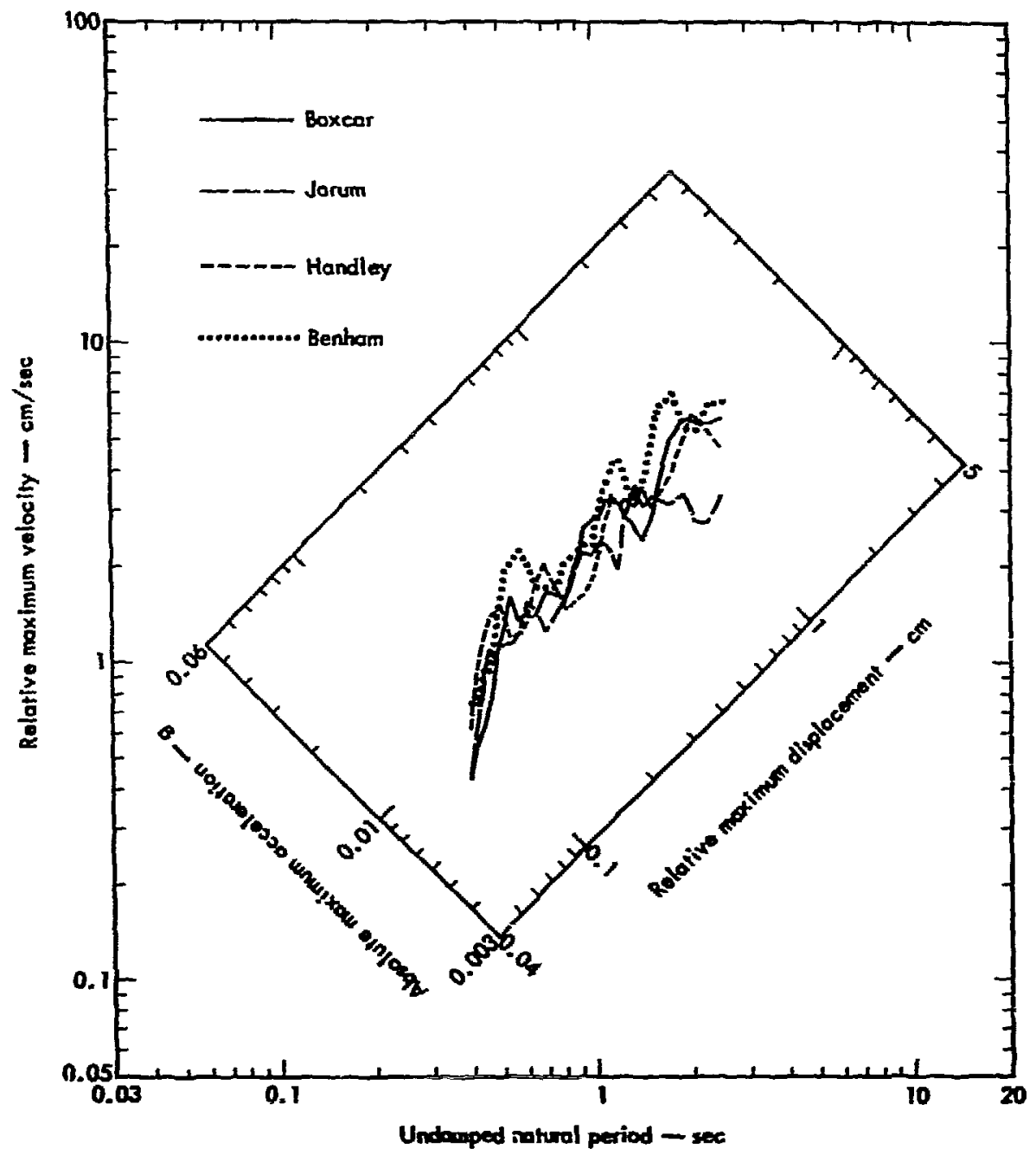

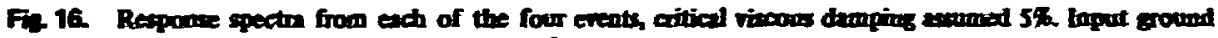
motion meagured at Squires Pat (S63\% E componaut).

\section{BEotRAL Restonse}

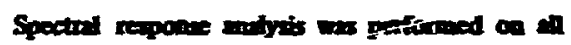

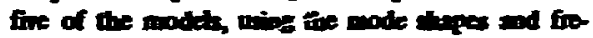

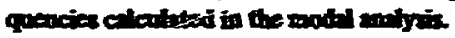

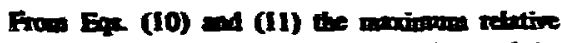

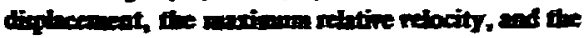

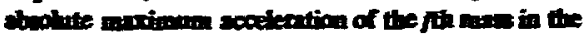




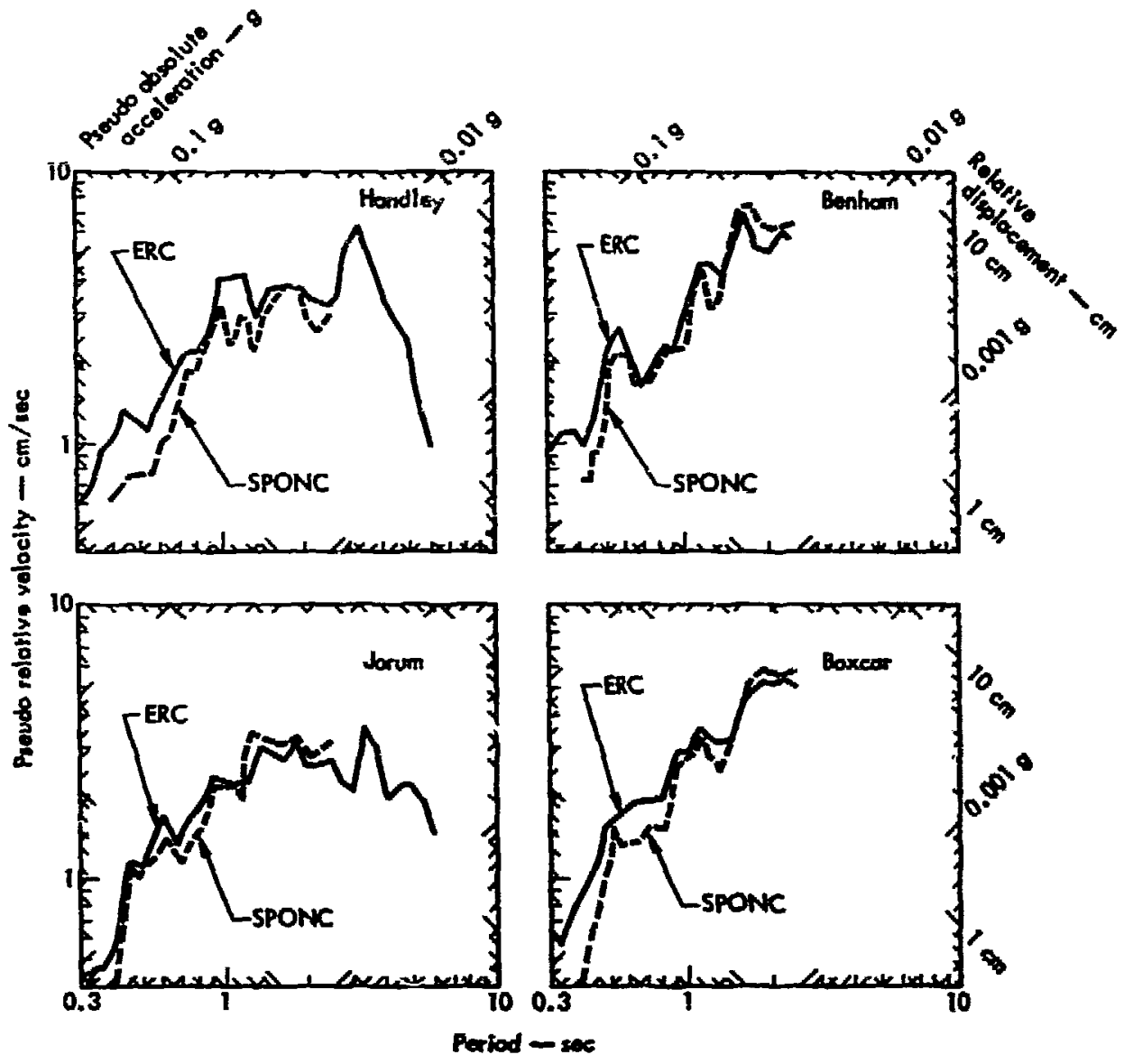

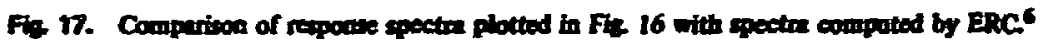

Th mode of a many-degres-officedom syteem on be exprened a

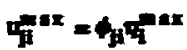

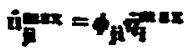

$$
\begin{aligned}
& \sum_{j}=\phi_{a}\left(\varepsilon_{1}+\gamma_{p}\right)^{a x}
\end{aligned}
$$

By comprine Eq, (IO) an (14) and also mint

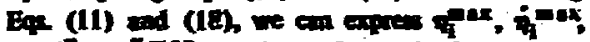

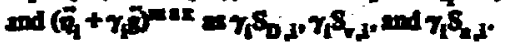

repectivity. Replacin the correporting teris in Eq. (20) by their qpectiol identitios rexitu in

$$
\begin{aligned}
& u_{j}^{\max }=\gamma_{1} s_{0, j} \\
& \text { pax }=x_{10} 8 \\
& y^{2 x}=r_{1} s_{1,}
\end{aligned}
$$

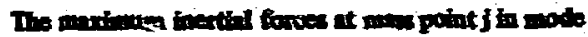
This tom to be

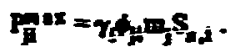




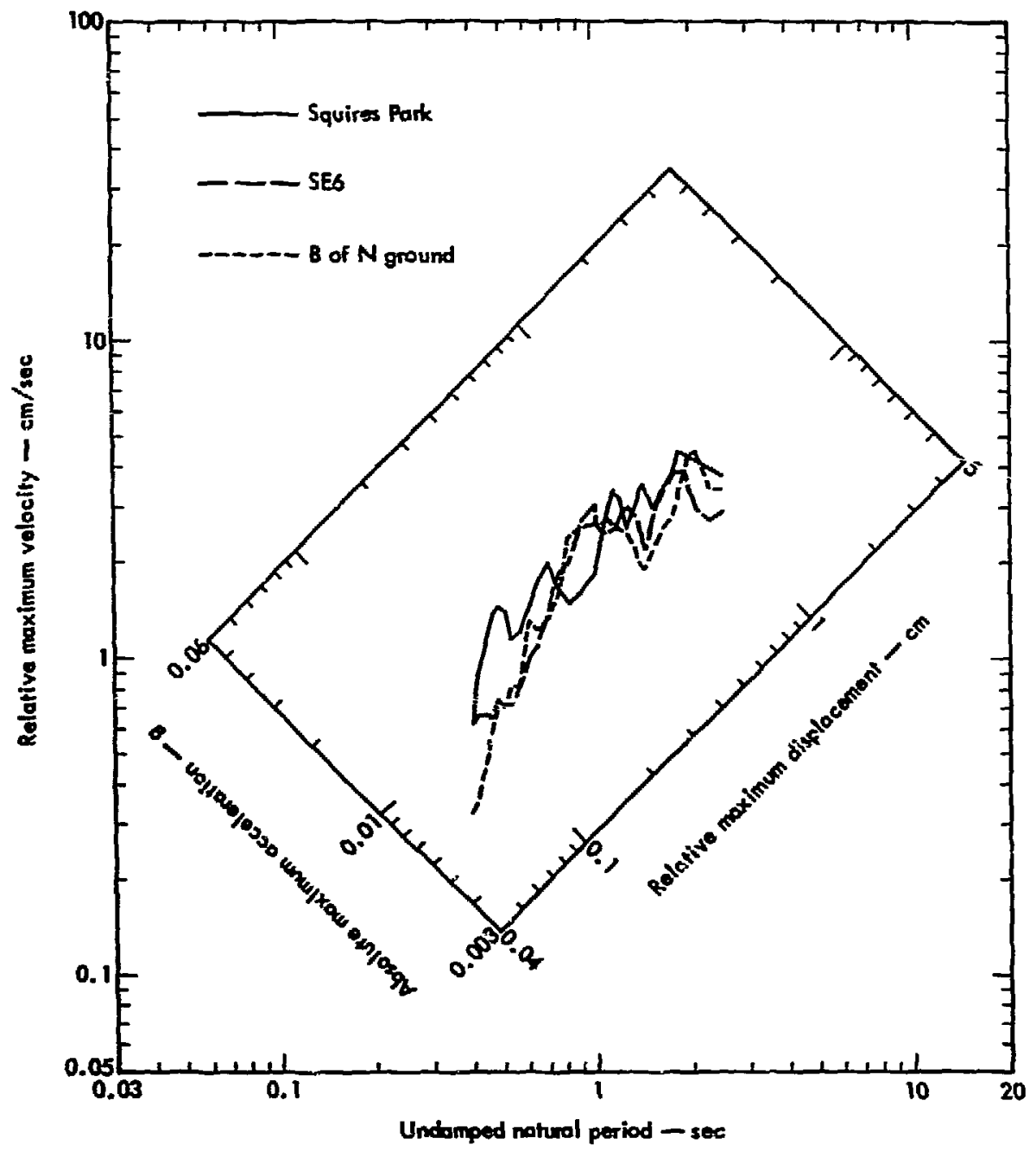

F4. 18. Rexponse spectu for Hendley Event, generated from ground motions measured at SE6, Squires Park, and at the bese of the $B$ of $N$ brildine $5 \%$ dumping ( $563^{\circ} \mathrm{E}$ component).

The maximam atong shear at the lond between $M$ and $M-1$ in mode $7^{\prime \prime}$ cm be exprased as

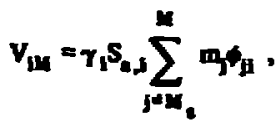

where $\mathrm{M}_{\mathrm{S}}$ is the number of kevels. The shear at the base of the system, asually referred to as "bese obtained by setting $\mathrm{M}=1$ in Eq. (23).

The moments in mode " $i$ " can be obtained by the summation of the forces multiplied by the height of 


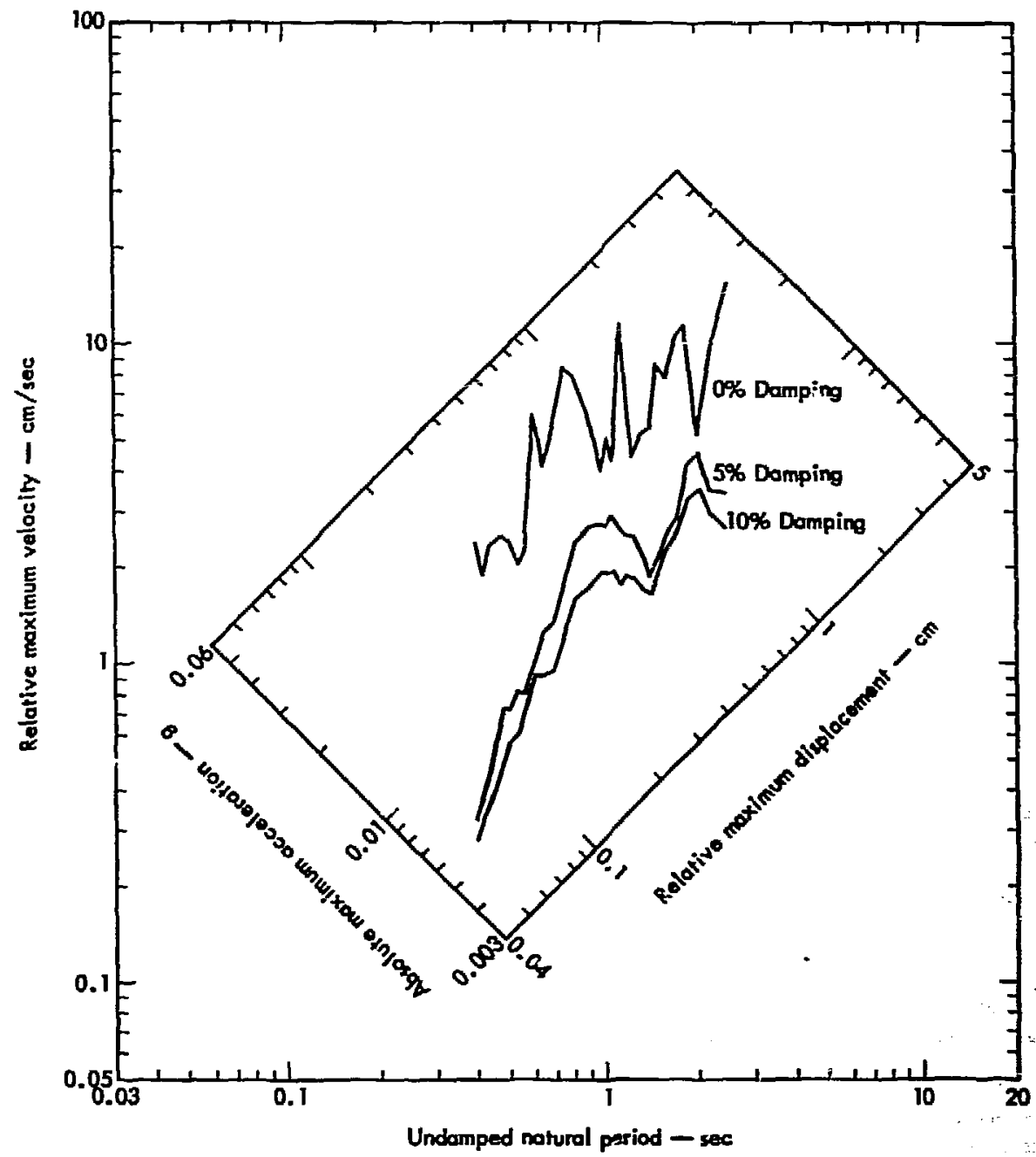

Fig. 19. Response spectra for Handley Event, generatod from ground motions mesumod at the bexe of the B of $N$ building for values of damping of 0,5 , and $10 \%$ ( $563^{\circ} \mathrm{E}$ component).

exch force above the point of interest. For example, the moment at the base of the system is

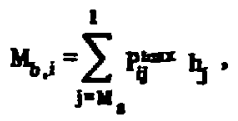

where $h_{1}=$ haight of mess $j$ abome the bese. It is improbable at any indent of tims thent the ppectral values (for example, $S_{\mathrm{D}, 1}, S_{\mathrm{D}_{2}, 2}$, and $S_{\mathrm{D}, 3}$ ) with $000 \mathrm{xu}$ simnltantously. Thus the spectrol repponse procodure does not permit the determination through-model combinations of maximum dioptacements, velpcitios, acceieration, forces, stears, of moments Approximetions ach as root-mean-auare or tholute win wo usuelly made. 


\section{Results}

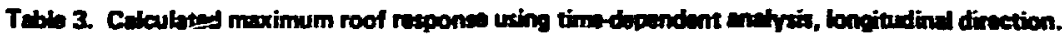

\begin{tabular}{|c|c|c|c|c|c|}
\hline Eneat & Stion & Maded & $\underset{(x)}{D+x}$ & 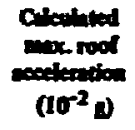 & $\begin{array}{l}\text { Coninied } \\
\text { (a) }\end{array}$ \\
\hline \multirow[t]{9}{*}{ Exasy } & $S_{4} \mathrm{Ft}$ & 16 & 2 & 3.7 & 1.sst \\
\hline & $S_{4} F_{L}$ & 16 & 5 & 23 & $1.25^{4}$ \\
\hline & Sq.F. & 16 & 10 & 1.5 & $12 x$ \\
\hline & 556 & 16 & 5 & 13 & aser \\
\hline & Bat $\mathrm{N}$ & 16 & 5 & 14 & ass \\
\hline & Bof $N$ & es & 5 & 20 & 10 \\
\hline & Bof $N$ & $\mathbf{u}$ & $\mathbf{s}$ & 2.2 & 1.08 \\
\hline & $\mathrm{Bof} N$ & 12 & 5 & 16 & 1.27 \\
\hline & Bof $N$ & $h 1$ & 5 & 25 & 150 \\
\hline Beshem & SqF & 16 & 5 & 23 & 1.300 \\
\hline Jaril & 847 & 16 & 5 & 16 & $1.10^{\circ}$ \\
\hline Dann & $S_{4} r_{k}$ & is & 5 & 1.4 & ans \\
\hline
\end{tabular}

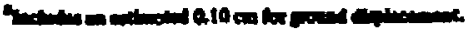

Tables 3 and 4 summarize the claculated peak roof reposeser, including both the ppectrol and the timedependent results. The ppectrol values were calculated by using the plots in Fig. 15, 16, and 19 and Eq. (21). Both the root-mem-aquare approximation and the sum of the absolute modal maxima are thown. Only the firut the modes participated effectively in the calculations As expected, becuse the builtin is viluating primarily in it fundmental mods, the agreenent between the spectril and time-dependent penk values is roy good.

The meserined peak roof responises are shown in Table 3 for all the orents considered. A comperien between the mesoured and calculated vihes indicates the importince of heving a refiable exciting motion and a relinble model; it also shows the variation in the celloulted reppoer.

A time-hintory reponse was calculated for each of the modele developed uxing the modal aperpasition mothod; in the difienent metwred ground motions were ned a exciting motion inpat. Only part of the remilts are inctuded. Figures 20 through 24 show the colculated timp-history reoponse of the ahsolute fir plecement of the roof, eighth and fifth floors for each of the five modeks. The exciting groumd motion wes the measured motion at the builing's bate for the

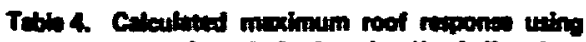

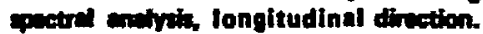
Hendily Emat, squires Part Station (SasE), Es dinping

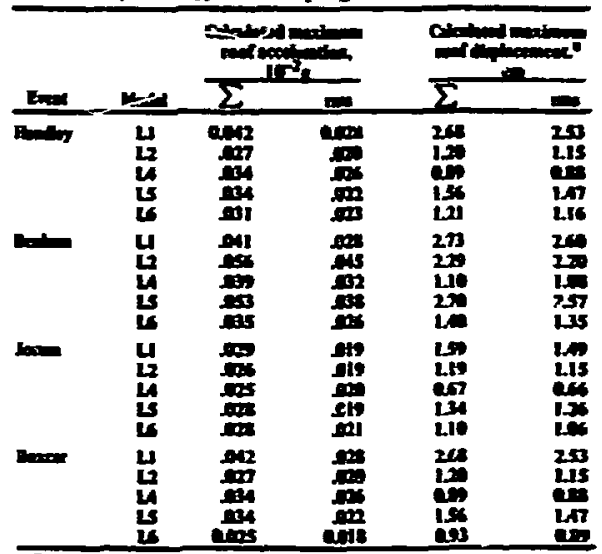

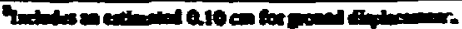

Fundley Event. Fin percent of critical viswows deuping wos sumed. Superimponed on each of the calculhted plots is the mexerred timehistory insponse. Since the exciting motion uned in the 


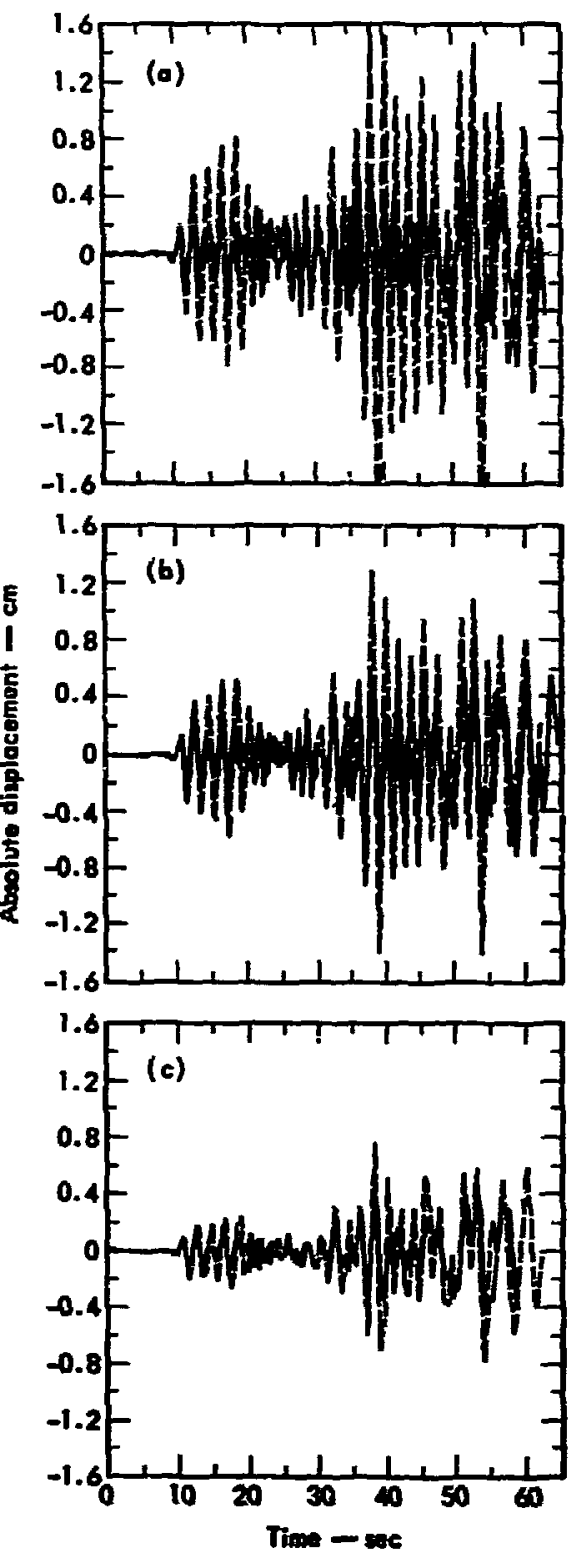

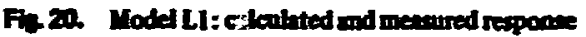
of (a) the roof, (b) fith ind (c) finth foos, Fundiey Event, $5 \%$ dumpine.

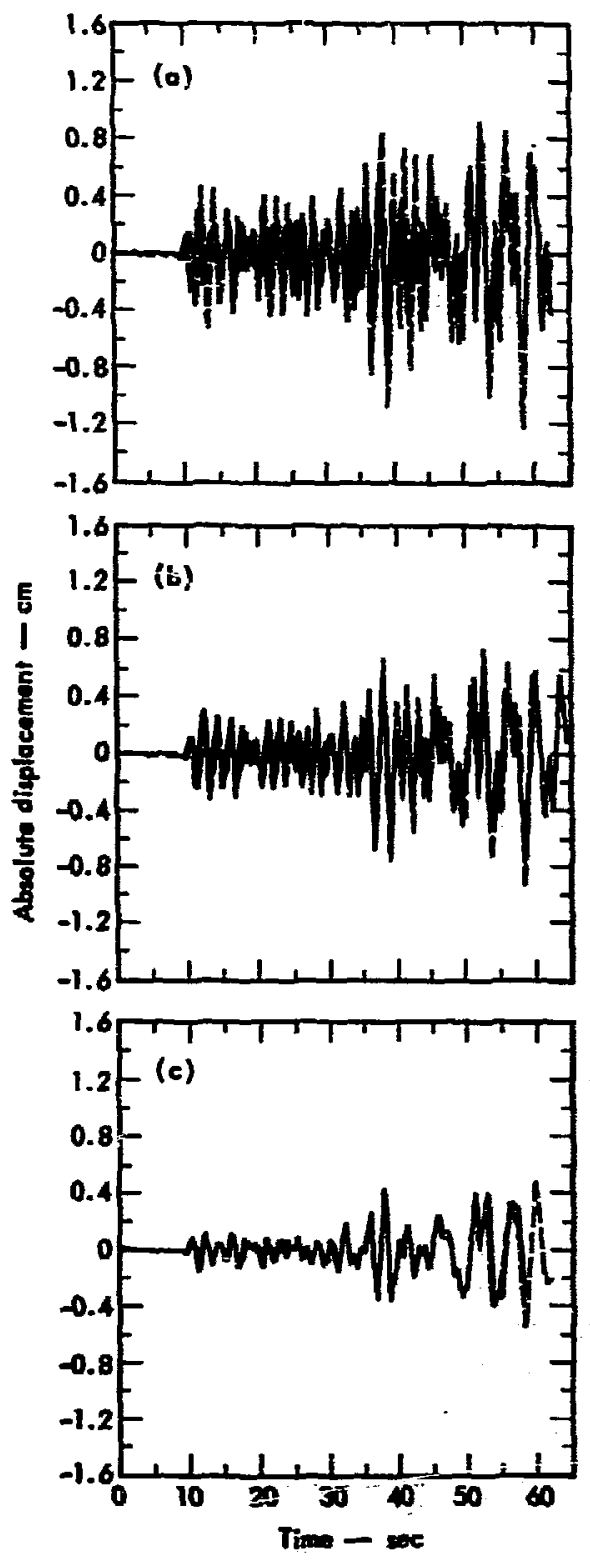

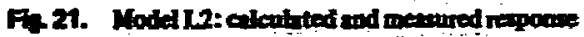
of (a) the roof, (b) elinh and (c) fifth Aoces Handey Event, S\% dampine 


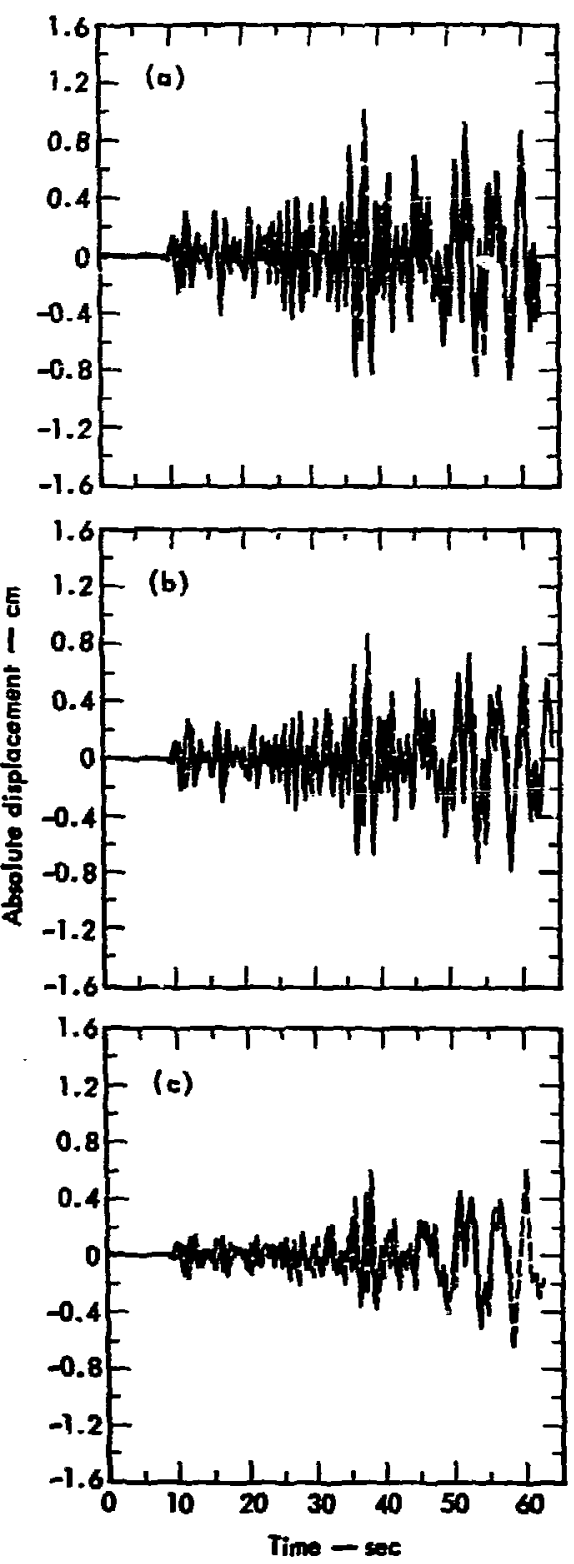

Fin 22. Moded LA: calcalated and merrured response of (o) the roof, (b) eighth and (c) ifth Dooss, Fandley Event, $5 \%$ damping.
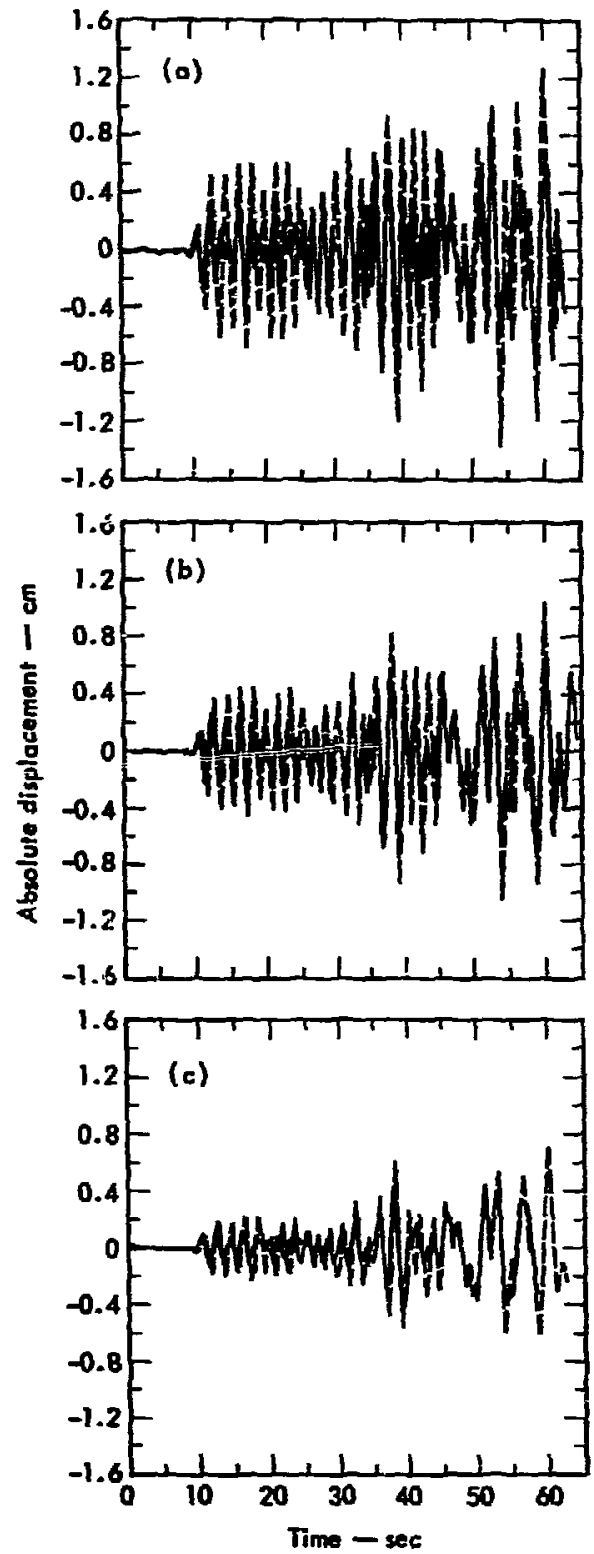

Fis 23. Model L5: calculated and measured response of (a) the roof, (b) eighth and (c) fifth floors, Fandley Event, 5\% damping. 

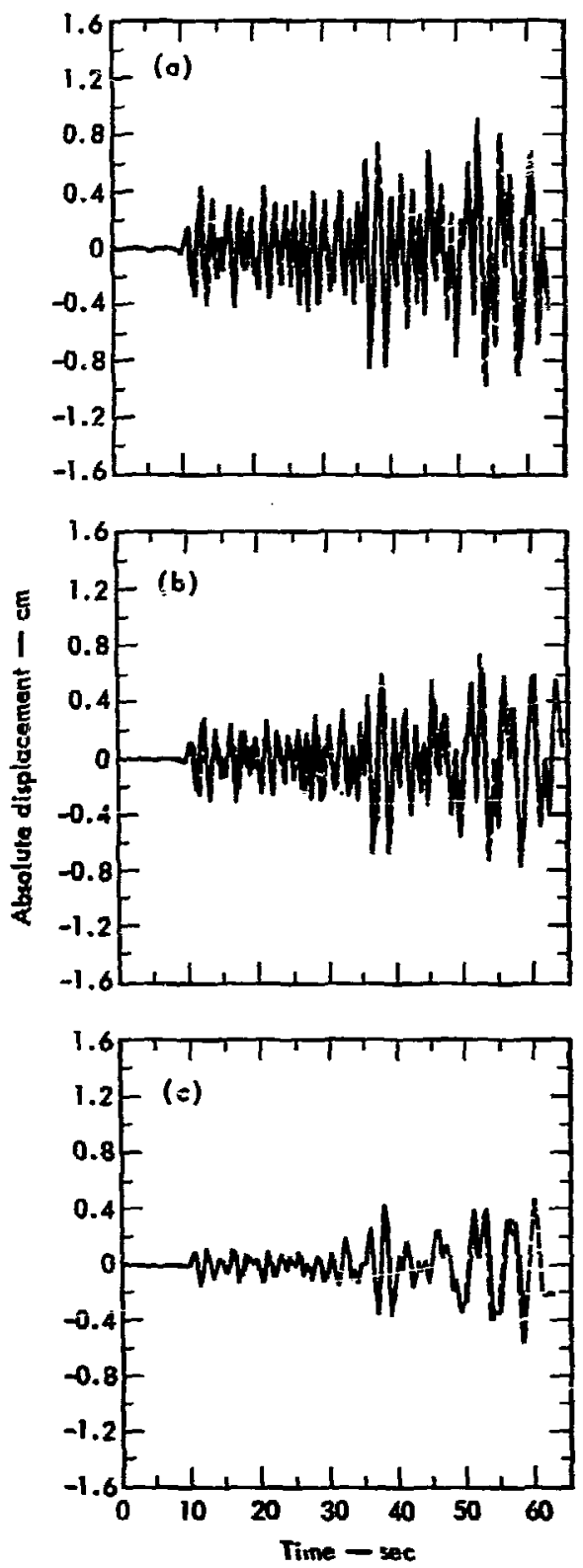

Fin 24. Model L6: calculinted and messured response of (a) the roof, (b) eighth and (c) Iffth Aloors, Hendiley Event, 5\% demping. figures is considered to be reliable, the variations in the calculated response spectro are assumed to result from the use of the diflerent models.

We from the frequres thit the calculated re sponse of model 26 agrees much more fanorabty irith the meaused response thin do the other modets. This wis expected for the following rexpon. All the models were developed before any meaured time-history information from the Hendley Event wes available. However, we did have peak response data for to roof, eighth, fith, fourth, and grousd ierels, and an eximute (1.37 sos) of the fundameatal period of the brititing (sec Table 1). Therefore, because the fundamental period of model 16 (1.46 sec) mont chocty agreen with the building's meacured funduments period and becauge modet 16 better reflects the incresed stiffees provided by tive puring garne in the lowe lerebs (aleo indicated by the penk meanured ro. sponer), this model was considered to best represent the builting (Note that in the absence of such information about the building's responee before the Fandiey Event, all decitions reganding its respone have to be based on a consideration of all models?

The timehistory retive tibiecement retponos at the roof is thow in FLE. 25 and 26 for model $L 6$ for different Exciturg fround motione Figire 25 how be calculated reppose for soverl events using the motion at Squires Path as the exciting input. Note that oven though these events were similar in yield, seographical location, and depth of burial, coutideralle rariation in the calcalated requonse is erident. Figure 26 considers only the Handley Event; the exciting ground motions were meapured at the base of the building, at Squires Part $(800 \mathrm{~m}$ awny), and at SE6 (7 km away). Agin considerable variation in the calculated response on be seen even though both the reconding stations, Squires Park and SE6, are quite close to the $B$ of $N$ building.

The variation of the calculated response for verious assumed values of percent viscouls damping can be seen in Table 3. A damping value of $5 \%$ sems to give the best agreement with measured data for bero-of-building exciting input; however, if Squines Part ground motion is used as input, a damping value of $10 \%$ seemis more reasonable. Bhumel hes atteropted to deduce the dempine value for a structure by using very approximate modals with Squires Putk ground motion inpat. Our

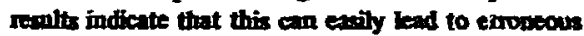
velues of damping. Thus it appean that the ves of any modal or exciting motion phich cannot be considad refinble could lead to an erroneous inference resenting the dumping value for a structure. 

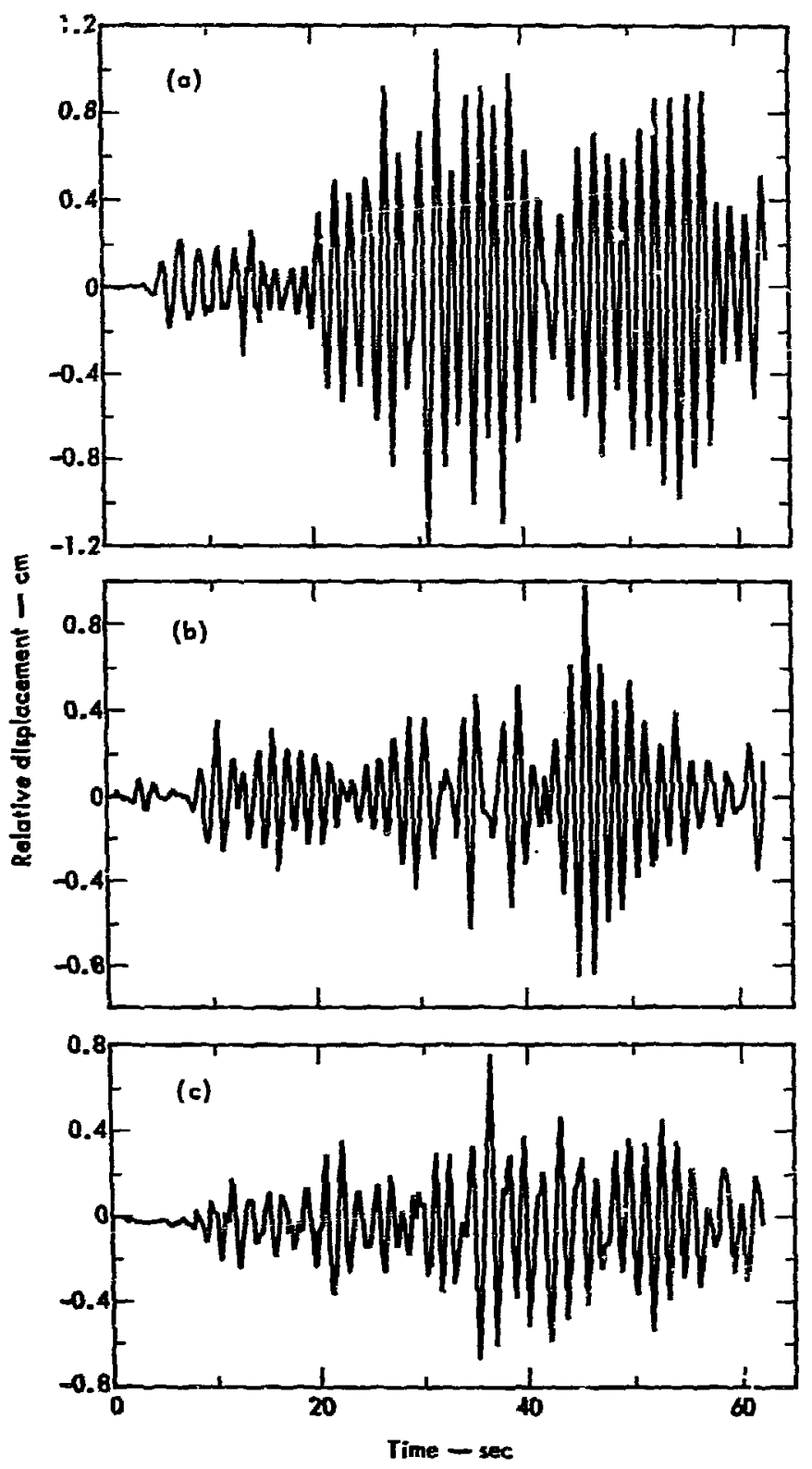

Fig -25. Calculated roof response artel L6, using ground motion at Squires Park as input. Everest was (a) Bentham, (b) Jorum, (c) Boxcar.

30 


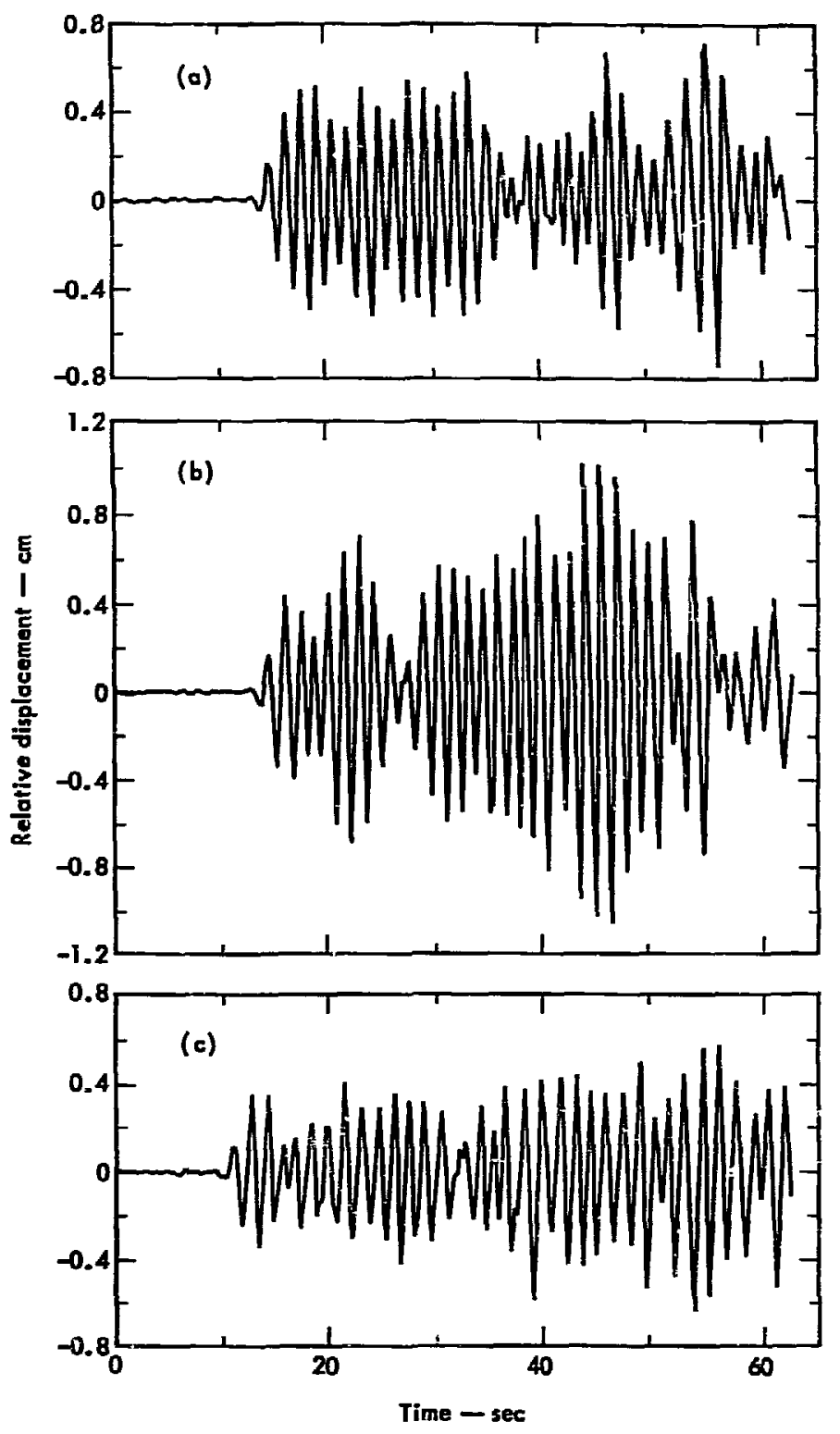

Fit 25. Calculated roof response, model L6, for Handley Event. Input was ground motion measured at (a) SE6, (b) Squires Park, (c) base of the buisting. 


\section{Summary and Conclusions}

This study has shown that:

(1) Both the elastic spectral approach and the time-dependent approach can reasonably predict the response of high-rise buildings to seismic motion when both the exciting motion and the model are reliable. Although the application of the time-dependent analysis requires more time and effort than the PSRV method, it reveals much more detailed information regarding the response of the structure. In addition, should the structure be vibrating in more than cne of its fundamental modes, the PSRV method will yield conservatrie estimates of the structure's response.

(2) The calculated response of the different possible models of the $B$ of $N$ building varied over a wide range for the same exciting motion, and also for different exciting motions when the same model was used. The effect of damping was also shown to be important.

There are several important points to note:

(I) All the models were reasonable models of the same building.

(2) All the ground motions were generated by nuclear explosions of very similar yield and geographic location and yet the character of the time histories and response spectra varied greatly from event to event and locally from station to station.

The results of this study indicate that modeling is extremely important and that miess empirical data exist for comparison, a range of models should be corstructed. No less important is the precision with which the ground motion an be predicted for any meaningful iesponse calculation.

\section{Acknowledgments}

The authors wish to express theis appreciation to V. N. Kappenko, head of Nuclear Test Engineering Division for initially sugzesting and supporting this study and to A. B. Miller for many helpful discussions.

In addition, the authors wish to thank John A Blume and Acsociates of San Francieco, in particular S. Freeman and $K$. Honda, for their helpful comments regarding the various buiding models and also for providing ws with the engineering drawings of the building and with ground motion dats. 


\section{Roforences}

1. J. A. Blume, The Motion and Dampling of Bulldings Relotive 10 Selsmic Response Spectra, U. S. Atomic Energy Commizwion, Lus Vega, Nev., Rept. JAB-99-72 (1969).

2. J. A. Blume, Response of Hilurise Bulldings to Ground Motion from Undernound Nuclear Detonations, $U$. S. Atomic Enerey Commistion, Las Vegas, Nev., Rept. JAB-99-71 (1969).

3. D. B. Hudson, A Compartson of Theoretical and Experimentel Determinations of Bulding Reaponie to Earthquakes, in Proc. 2nd World Conf. on Earthquake Ene. Tokyo, Japan (Science Council of Japan, Tokyo, Japan, 1960).

4. K. W. King, Preliminary Callbration of the SCATT-I System, U. S. Dept. of Commence Special Projects Party, Las Vegas, Nov., Rept. CGS-C-119 (1968).

5. D. L. Watson, Environmental Research Cosp. Procedures for NC-21 Imstrument Correction, U. S. Atomic Enerey Commiculon, La Veen, Nov., Rept. NVO-1163-115 (1967).

6. J. R. Frock, J. L. Hannah, N.M. Lutz, and G. P. Smith, ERC Date Procesolne Syatem, U. S. Atomic Enery Cosmiscton, Lar Vegen, Nov., Rept. NVO-1 163-168 (1969).

7. J. W. Bige, Introduction to Siructural Dynamics (McGraw Hill, N. Y., 1964), pp. 329-333.

8. H. Goldstein, Classical Mechantes (Addison Wodley, Readins, Man., 19:50), pp. 318-333.

9. F. B. Hildebrand, Methods of Applled Mathemotics (Prentico-Hall, Endewood Cilf, N. J., 1960), Pp. 83-87.

10. D. L. Bernreuter, to be published. 


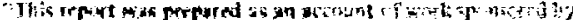

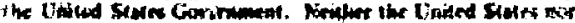

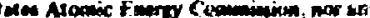

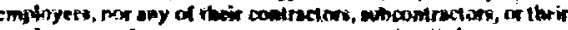

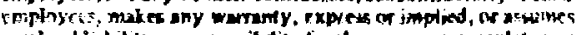

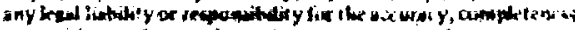

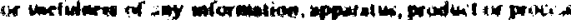

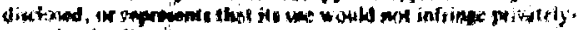
oward ridito.

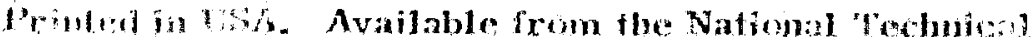

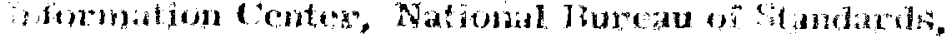

I. S. Department of Commerce, Sirringlield, Virginia 227 il

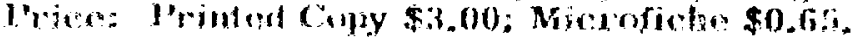

